\title{
Sagittal spinal morphotype assessment in 8 to 15 years old Inline Hockey players
}

\author{
Pilar Sainz de Baranda ${ }^{1}$, Antonio Cejudo ${ }^{\text {Corresp., }}{ }^{1}$, Victor Jesus Moreno-Alcaraz ${ }^{1}$, Maria Teresa Martinez-Romero ${ }^{1}$, \\ Alba Aparicio-Sarmiento ${ }^{1}$, Fernando Santonja ${ }^{2}$ \\ ${ }^{1}$ Department Physical Activity and Sport / Faculty of Sport Sciences / Campus of Excellence Mare Nostrum, Universidad de Murcia, Murcia, Spain \\ 2 Department Orthopaedic Surgery, Pediatrics, Obstetrics and Gynecology, "Virgen de la Arrixaca" University Hospital / Faculty of Medicine / Campus of \\ Excellence Mare Nostrum, Universidad de Murcia, Murcia, Spain \\ Corresponding Author: Antonio Cejudo \\ Email address: antonio.cejudo@um.es
}

Background. Physiological sagittal spinal curvatures play an important role in health and performance in sports. For that reason, several scientific studies have assessed spinal morphology in young athletes. However, to our knowledge, no study has assessed the implications of Inline Hockey (IH) practice on sagittal integrative spinal morphotype in adolescent players.

Objectives. The aims of the present study were to describe habitual sagittal spinal posture in young federated IH players and its relationship with training load and to determine the sagittal integrative spinal morphotype in these players.

Methods. An observational analysis was developed to describe the sagittal spinal morphotype in young federated IH players. A total of $74 \mathrm{IH}$ players from the Technification Plan organized by the Skating Federation of the Valencian Community (aged from 8 to 15 years) participated in the study. Thoracic and lumbar curvatures of the spine were measured in a relaxed standing position (SP), in a slump sitting position (SSP) and in maximum flexion of the trunk (MFT) to determine the "Sagittal Integrative Morphotype" of all players. An unilevel inclinometer was used to quantify the sagittal spinal curvatures. The Hip Joint Angle test was used to quantify the Lumbo-Horizontal angle in flexion (L-Hfx) of all participants with a goniometer.

Results. When thoracic curvature was analysed according to normality references, it was found that $64.9 \%$ of IH players had thoracic hyperkyphosis in a SSP, while $60.8 \%$ and $74.3 \%$ of players were classified as normal in a SP and in MFT, respectively. As for the lumbar curve, $89.2 \%$ in a SP and $55.4 \%$ in MFT were normal, whereas $68.9 \%$ of IH players presented lumbar hyperkyphosis in a SSP. Regarding the "Sagittal Integrative Morphotype", only $\mathbf{1 7 . 6 \%}$ of players were classified as "Normal" in the three measured positions for the thoracic curve, while 37.8\% had "Thoracic Hyperkyphosis" and 41.8\% presented "Functional Thoracic Hyperkyphosis". As for the "Sagittal Integrative Lumbar Morphotype", only $23 \%$ of athletes had a normal curve in the three positions, whereas $66.2 \%$ presented "Functional Lumbar Hyperkyphosis". When the L-Hfx was evaluated, the results showed that only $16.2 \%$ of the athletes were classified as normal.

Conclusions. Federative IH practice seems to cause specific adaptations in spinal sagittal morphotype. Taking into account the "Sagittal Integrative Morphotype" only 17.6\% IH players presented "Normal Morphotype" with a normal thoracic kyphosis in the three measured positions, while only $23 \%$ IH players presented "Normal Morphotype" with a normal lumbar curvature in the three assessed positions. Furthermore, only $16.2 \%$ of IH players showed normal pelvic tilt. Exercise programs to prevent or 
rehabilitate these imbalances in young $\mathrm{IH}$ players are needed. 


\section{Sagittal spinal morphotype assessment in 8 to 15}

\section{2 years old Inline Hockey players}

3

4 Pilar Sainz de Baranda ${ }^{1}$, Antonio Cejudo ${ }^{1}$, Víctor Jesús Moreno-Alcaraz ${ }^{1}, \mathrm{M}^{\mathrm{a}}$ Teresa Martinez-

5 Romero $^{1}$, Alba Aparicio-Sarmiento ${ }^{1}$, Fernando Santonja ${ }^{2}$

6

$7 \quad{ }^{1}$ Department of Physical Activity and Sport, Faculty of Sport Sciences, Campus of Excellence

8 Mare Nostrum, University of Murcia, Murcia, Spain.

9 'Department of Orthopaedic Surgery, Pediatrics, Obstetrics and Gynecology, "Virgen de la

10 Arrixaca" University Hospital, Faculty of Medicine, Campus of Excelence Mare Nostrum,

11 University of Murcia, Murcia, Spain.

Corresponding Author:

14 Antonio Cejudo ${ }^{1}$

15 C/Argentina 19, Faculty of Sport Sciences, San Javier, 30720, Murcia, Spain

16 E-mail address: antonio.cejudo@um.es

17

18

19

20

21

22

23

24

25

26

27

28

29

30

31

32

33

34

35

36

37

38

39 
40

41

42

43

44

45

46

47

48

49

50

51

52

53

54

55

56

57

58

59

60

61

62

63

64

65

66

67

68

69

70

71

72

73

74

75

76

77

78

79

\section{Abstract}

Background. Physiological sagittal spinal curvatures play an important role in health and performance in sports. For that reason, several scientific studies have assessed spinal morphology in young athletes. However, to our knowledge, no study has assessed the implications of Inline Hockey $(\mathrm{IH})$ practice on sagittal integrative spinal morphotype in adolescent players.

Objectives. The aims of the present study were to describe habitual sagittal spinal posture in young federated IH players and its relationship with training load and to determine the sagittal integrative spinal morphotype in these players.

Methods. An observational analysis was developed to describe the sagittal spinal morphotype in young federated IH players. A total of $74 \mathrm{IH}$ players from the Technification Plan organized by the Skating Federation of the Valencian Community (aged from 8 to 15 years) participated in the study. Thoracic and lumbar curvatures of the spine were measured in a relaxed standing position (SP), in a slump sitting position (SSP) and in maximum flexion of the trunk (MFT) to determine the "Sagittal Integrative Morphotype" of all players. An unilevel inclinometer was used to quantify the sagittal spinal curvatures. The Hip Joint Angle test was used to quantify the LumboHorizontal angle in flexion (L-Hfx) of all participants with a goniometer.

Results. When thoracic curvature was analysed according to normality references, it was found that $64.9 \%$ of IH players had thoracic hyperkyphosis in a SSP, while $60.8 \%$ and $74.3 \%$ of players were classified as normal in a SP and in MFT, respectively. As for the lumbar curve, $89.2 \%$ in a SP and $55.4 \%$ in MFT were normal, whereas $68.9 \%$ of IH players presented lumbar hyperkyphosis in a SSP. Regarding the "Sagittal Integrative Morphotype", only $17.6 \%$ of players were classified as "Normal" in the three measured positions for the thoracic curve, while 37.8\% had "Thoracic Hyperkyphosis" and 41.8\% presented "Functional Thoracic Hyperkyphosis". As for the "Sagittal Integrative Lumbar Morphotype", only 23\% of athletes had a normal curve in the three positions, whereas 66.2\% presented "Functional Lumbar Hyperkyphosis". When the LHfx was evaluated, the results showed that only $16.2 \%$ of the athletes were classified as normal. Conclusions. Federative IH practice seems to cause specific adaptations in spinal sagittal morphotype. Taking into account the "Sagittal Integrative Morphotype" only $17.6 \%$ IH players presented "Normal Morphotype" with a normal thoracic kyphosis in the three measured positions, while only 23\% IH players presented "Normal Morphotype" with a normal lumbar curvature in the three assessed positions. Furthermore, only $16.2 \%$ of IH players showed normal pelvic tilt. Exercise programs to prevent or rehabilitate these imbalances in young IH players are needed.

Keywords: spine, alignment, young athlete, morphotype, injury

\section{Introduction}


80 Physiological sagittal spinal curvatures play an important role in health and performance in 81 sports since the distribution of mechanical strains greatly affects the structures of the spine and 82 can influence athletes' stability as well as result in overuse injuries to the spine (Keller, Colloca, 83 Harrison, Harrison, \& Janik, 2005). Hence, these curvatures should be neither reduced nor 84 excessive in order to maintain a physiological, harmonic and balanced posture. In this sense, to 85 have sagittal spinal curvatures within the normal ranges could favour the athlete's trunk mobility 86 as well as improve a player' stability due to the lower centre of gravity and the better distribution 87 of the load (Ackland, Elliott, \& Bloomfield, 2009).

88 It must be noted that sagittal misalignments of the spine alter the loads distribution and increase 89 even more the stress on the different joint tissues, therefore, an unbalanced sagittal spine 90 91 92 93 94 95 predisposes to back problems. Previous studies have found that an increased thoracic or lumbar curvature has been related to spinal pain (Christie, Kumar, \& Warren, 1995; Ohlén, Wredmark, \& Spangfort, 1989; Roncarati \& McMullen, 1988; Salminen, Maki, Oksanen, \& Pentti, 1992; Salminen, Oksanen, Mäki, Pentti, \& Kujala, 1993), as well as to certain pathologies in the spine (Katz \& Scerpella, 2003; Swärd, Hellstrom, Jacobsson, \& Pëterson, 1990). For instance, it has been observed instability of the spine in kyphotic lumbar postures (Green, Grenier, \& McGill, 2002; Jackson, Solomonow, Zhou, Baratta, \& Harris, 2001; Solomonow, Zhou, Baratta, Lu, \& Harris, 1999), disc protrusion in hyperkyphotic postures (Callaghan \& McGill, 2001; Simunic, Broom, \& Robertson, 2001), herniated disc when the lumbar curve is inverted or kyphotic (Micheli \& Trepman, 1990), anterior vertebral wedges (Santonja \& Martínez, 1995), Schmorl nodules or vertebral plate abnormalities (Callaghan \& McGill, 2001; McGill, 2002) in hyperkyphotic and inverted positions of the lumbar spine, and facet degeneration and spondylolysis in hyperlordotic postures (Micheli \& Trepman, 1990). These negative consequences justify the research on the relationship between systematic sports training and the alignment of sagittal spinal curvatures (Santonja \& Morales, 2008).

For those reasons, several experts in the analysis of the locomotor system recommend the assessment of sagittal spinal curvatures to describe the sagittal morphotype of spine in sports (Sainz de Baranda et al., 2010; Sainz de Baranda \& Santonja, 2009; Santonja \& Pastor, 2000; Sanz-Mengibar, Sainz-de-Baranda, \& Santonja, 2018). In fact, this knowledge could contribute to the development of more effective preventive interventions to be adopted by a multidisciplinary professional team. Specifically, for the assessment of the sagittal plane of the spine, it is recommended to evaluate the thoracic and lumbar curves in a standing position, in a slump sitting position and in maximum flexion of the trunk to finally establish the "Sagittal Integrative Morphotype" of the spine (Santonja, 1996). In addition, as the spine of an adolescent is in a maturation period, it shows changes in posture and balance of its curvatures during growth and it is more vulnerable (Sainz de Baranda, Rodríguez, Santonja, \& Andújar, 2006). Thus, sports professionals should be aware of the loads and overloads inherent in sport and training and its impact on the young athlete's spine (Sainz de Baranda, Rodríguez-García, \& Santonja, 2010). 
119 Therefore, several scientific studies have assessed spinal morphology in young athletes as

120

121

122

123

124

125

126

127

128

129

130

131

132

133

134

135

136

137

138

139

140

141

142

143

144

145

146

147

148

149

150

151

152

153

154

155

156

157

professional soccer players (Sainz de Baranda et al., 2001), basketball players (Ferreira-Guedes \& Amado-João, 2014; Grabara, 2016), handball players (Grabara, 2014), volleyball players (Grabara, 2015), rhythmic gymnasts (F. Martínez-Gallego \& Rodríguez-García, 2005; Ohlén et al., 1989), swimmers (Pastor, Santonja, Ferrer, Domínguez, \& Canteras, 2002; Santonja \& Pastor, 2000), dancers of Spanish and Classical dance (Gómez-Lozano, 2007), cricket players (Hecimovich \& Stomski, 2016), cross-country skiers (Alricsson et al., 2016) and wrestling (Rajabi, Doherty, Goodarzi, \& Hemayattalab, 2008). Other studies, included athletes of different sports (Betsch et al., 2015; Grabara, 2014; Lichota, Plandowska, \& Mil, 2011; Wojtys et al., 2000). However, to the best of our knowledge, no study has assessed the implications of Inline Hockey (IH) practice on "Sagittal Integrative Spinal Morphotype" in adolescent players. The participation in Inline roller hockey or IH among adolescents has increased in the past few years thanks to the popularity of inline-skating. Since its introduction in 2000 in Spain, IH has been one of the fastest growing sports in the different federative categories. Over the 2005/06 and 2016/17 seasons, there were 3100 and 5234 licenses, respectively, which is an increase of almost $60 \%$ in the number of licenses within the last ten years (Real Federación Española de Patinaje, 2018).

In order to find out how IH can affect young players' spine as well as to help sport professionals to plan specific preventive interventions, the current investigation was carried out. The aims of the present study were 1) to describe habitual sagittal spinal posture in young federated $\mathrm{IH}$ players and its relationship to training load, and 2) to determine the "Sagittal Integrative Spinal Morphotype" in these players. Our hypothesis is that there is a special adaptation of the spine to the specific requirements of $\mathrm{IH}$ in young players.

\section{Materials \& Methods}

In order to confirm or rule out our hypothesis, an observational analysis was developed to describe the sagittal spinal morphotype in young federated IH players.

The study was approved by the Ethics and Research Committee of the University of Murcia (Spain) [ID: 1702/2017].

\section{Participants}

The subject population was selected through a convenience sample from the Technification Plan organized by the Skating Federation of the Valencian Community in the season 2016-17, in which the best IH players of the Valencian Community took part in (Castellón de la Plana, Region of Valencia, Spain). A total of $90 \mathrm{IH}$ players from the Skating Federation of the Valencian Community were selected to participate in this study.

Following the inclusion criteria, those who were from 8 to 15 years old and were playing within the Spanish Federative Categories of "Benjamín" (U11) "Alevín" (U13) and "Infantil" (U16) were included in the study ( $\mathrm{n}=77)$, whereas goalkeepers and players who belonged to the U17 team were not included $(\mathrm{n}=15)$. However, those who had previously received treatment for any frontal or sagittal plane-related pathology by the use of a corset or specific kinesiotherapy or 
158 those who presented specific symptoms or musculoskeletal limitations to perform the tests

159 correctly were excluded $(\mathrm{n}=1)$.

160 Finally, a total of $74 \mathrm{IH}$ players U16 participated in the study (Table 1).

$161 * * *$ Insert table 1 here ${ }^{* * *}$

\section{Procedure}

163 The study was conducted in the season 2016-17. According to the Declaration of Helsinki, the

164

165

166

167

168

169

170

171

172

173

174

175

176

177

178

179

180

181

182

183

184

185

186

187

188

189

190

191

192

193

194

195

196

197 procedures and potential risks were explained to IH players, parents and coaches prior to participation and legal tutors expressed written consent.

"Sagittal Integrative Morphotype", as well as Lumbo-Horizontal angle in flexion (L-H fx) of all participants, were assessed. In addition, participants completed an ad hoc questionnaire about their sport-related background (federative category, current competitive level, tactical position, stick length, dominant leg [defined as the participant's preferred kicking leg]), anthropometric characteristics (age, weight, height and body mass index), regular training workload (years of sport experience, training months per year, training days per week, training hours per week, current competitive level) as well as about prior and current musculoskeletal injuries and treatment.

According to Wojtys et al. (2000) and Sainz de Baranda, Rodríguez-García, \& Santonja (2010b), "training hours per year" and "training volume" were calculated. "Training hours per year" was equal to training hours per week $\mathrm{x} 4$ weeks per month $\mathrm{x}$ months per year. "Training volume" was equal to years of sport experience $\mathrm{x}$ training hours per year. Two groups were established based on those who had trained more or less than 160 hours per year. The players were also divided according to the accumulated training workload in more or less than 480 hours of training.

\section{Sagittal spinal morphotype assessment}

Data from each IH player were taken during the same assessment session and with the same temperature $\left(25^{\circ} \mathrm{C}\right)$. All the measurements were performed by the same Sport Science expert and participants were assessed wearing undergarments and barefoot. Athletes did not perform warmup or stretching exercises before or during the measurement in order to achieve real clinical conditions (Aalto, Airaksinen, Härkönen, \& Arokoski, 2005; Cejudo, 2015; Ginés-Díaz, Martínez-Romero, Cejudo, Aparicio-Sarmiento, \& Sainz de Baranda, 2019).

An unilevel inclinometer (ISOMED, Inc., Portland, OR) was used to quantify the sagittal spinal curvatures by providing considerable reproducibility and validity, with a good correlation with the radiographic measurement (Mayer, Tencer, Kristoferson, \& Mooney, 1984; Saur, Ensink, Frese, Seeger, \& Hildebrandt, 1996), and according to the methodology described by Santonja (1996), which has been used in previous studies (Ginés-Díaz et al., 2019; Sainz de Baranda, Santonja, \& Rodríguez-Iniesta, 2009; Sanz-Mengibar et al., 2018). A goniometer provided with a spirit level system was used to quantify the L-H fx (Sainz de Baranda, Rodríguez-Iniesta, Ayala, Santonja, \& Cejudo, 2014; Santonja, Andújar, \& González-Moro, 1994). Intra-tester reliability of thoracic and lumbar curvatures and pelvic tilt was calculated in a previous pilot study. A priori reliability was established by the primary investigator in a sample of convenience (university students; $\mathrm{n}=12$, ranged from age $=20-22$ years; (age: $25.8+0.9$ years; 
198 height: $1.71+0.09 \mathrm{~m}$; body mass: $72.05 \pm 9.28 \mathrm{~kg}$ ) measured on two occasions by the same tester 199 in a single session. Intra-class correlation coefficients (ICC) with $95 \%$ confidence intervals (CI) 200 were calculated. The intraclass correlation coefficient (ICC) and the minimal detectable change 201 at a 95\% confidence interval (MDC95) values for all measures ranged from 0.88 to 0.97 (95\% 202 CI: $0.70-0.99)$ and $0.53^{\circ}$ to $1.1^{\circ}$ respectively (95\% CI: $\left.0.38^{\circ}-1.6^{\circ}\right)$.

203 The assessment protocol of "Sagittal Integrative Morphotype" as defined by Santonja (1996) is 204 composed by the evaluation of sagittal spinal curvatures in a relaxed standing position (SP) 205 (figure 1A), in a slump sitting position (SSP) (figure 1B) (Sainz de Baranda, Rodríguez, 206 Santonja, López-Miñarro, et al., 2006; Sainz de Baranda et al., 2009; Sainz de Baranda, 207 Santonja, \& Rodriguez-Iniesta, 2010; Santonja, 1996) as well as in maximum flexion of the 208 trunk (MFT) (figure 1C) (López-Miñarro, Sainz de Baranda, Rodríguez-García, \& Ortega, 2007; Sainz de Baranda et al., 2010; Sainz de Baranda et al., 2009; Sanz-Mengibar et al., 2018). This

210

211 protocol is performed in order to have a more accurate diagnostic of sagittal spinal morphotype (López-Miñarro et al., 2007; Norkin \& White, 1995; Sainz de Baranda et al., 2010; Sainz de

212 Baranda et al., 2009; Sanz-Mengibar et al., 2018).

$213 * * *$ Insert figure 1 here $* * *$

214 Prior to data collection, the spinous process of the first thoracic vertebra (T1), twelfth thoracic 215 vertebra (T12) and fifth lumbar vertebra (L5-S1) were marked on the skin of participants (López216 Miñarro et al., 2007; Norkin \& White, 1995; Sainz de Baranda et al., 2010; Sainz de Baranda et 217 al., 2009; Sanz-Mengibar et al., 2018).

218 Standing position

219 To assess the SP, the participant was standing and relaxed (Ginés-Díaz et al., 2019; Sanz-

220 Mengibar et al., 2018). The inclinometer was placed at the first mark (T1) and calibrated to $0^{\circ}$, 221 then the curvature was profiled until maximum angulation of thoracic curvature was reached and 222 the angle was recorded. Subsequently, the inclinometer was calibrated to $0^{\circ}$ again at this point 223 and the lumbar curvature was profiled until the maximum angle was reached and recorded. 224 Slump sitting position

225 To measure the SSP, the participant was sitting on the stretcher in a relaxed posture with the 226 forearms resting on the thighs, knees flexed and without feet support (Ginés-Díaz et al., 2019; 227 Sanz-Mengibar et al., 2018). First, the inclinometer was placed at the first mark (T1) and it was 228 calibrated to $0^{\circ}$. Then, the inclinometer would be placed on the second mark (T12) and the 229 grades for the thoracic curve would be recorded. After that, the inclinometer was calibrated to $0^{\circ}$ 230 again on this mark and then the inclinometer was placed on the third mark (L5-S1) in order to 231 record the lumbar curve angle.

232 However, the same procedure as in standing position was used when it was observed that 233 participants kept their lumbar lordosis in this position.

234 Maximum flexion of the trunk (MFT) in a Toe-Touch test position

235 Firstly, participants were standing on a box $36 \mathrm{~cm}$ high with their feet bare and hip-width apart.

236 They were asked to flex the trunk as far as possible, while knees, arms and fingers were fully 237 extended. 
238 The athlete had to keep the maximum flexion of the trunk for 6-8 seconds while sagittal spinal 239 curvatures were measured following the same procedure as in the SSP (Sainz de Baranda et al., 240 2014).

241 References of normality for thoracic and lumbar curves

242 The references of normality for thoracic and lumbar curves in each assessed position are 243 described in Table 2.

$244 * * *$ Insert table 2 here ${ }^{* * *}$

245 Sagittal integrative morphotype diagnosis

246 Table 3 and 4 detail the different categories and subcategories for the integrative diagnosis of the 247 sagittal integrative thoracic and lumbar morphotype, respectively.

$248 * * *$ Insert tables 3 and 4 here***

\section{Hip joint angle (HJA) test: $L-H$ fx}

250 The HJA is a field-based test that might be proposed as an alternative to the Passive Straight Leg 251 Raise test (PSLR) or the Sit and Reach test (SRT) for the assessment of hamstrings flexibility.

252 The score achieved in this test is not negatively influenced by the pelvic position or stability and 253 only one examiner and an inexpensive gravity goniometer are required (Ayala, Sainz de 254 Baranda, Cejudo, \& Santonja, 2013; Sainz de Baranda et al., 2014). The HJA test can be 255 measured at the end point of maximal trunk flexion in a horizontal or vertical position (Ayala et 256 al., 2013; Pilar Sainz de Baranda et al., 2014).

257 In the current study, the L-H fx was measured with a goniometer while the subject was 258 performing a maximum flexion of the trunk in a horizontal position (Sainz de Baranda et al., 259 2014; Santonja, 1996; Santonja, Ferrer, \& Andújar, 1994). The branches of the goniometer were 260 aligned with the horizontal line and the spinous processes of L4-S1 in order to record the angle 261 between the two references, however, the supplementary angle was used for the data analysis 262 (figure 2). Pelvic tilt data were classified as normal $\left(<100^{\circ}\right)$, mild posterior pelvic tilt $\left(100^{\circ}\right.$ to $\left.263110^{\circ}\right)$ and moderate posterior pelvic tilt $\left(>110^{\circ}\right)$.

$264 * * *$ Insert figure 2 here $* * *$

265 Statistical analysis

266 Descriptive statistics including means and standard deviations, minimum and maximum were 267 calculated for each variable: age, weight, height, BMI, training hours per year, training volume, 268 sagittal spinal angles in SP, SSP and MFT and sagittal pelvic disposition.

269 Prior to the statistical analysis, the distribution of raw data sets was checked using the 270 Kolmogorov-Smirnov test to determine normal distribution. The results demonstrated that the 271 sagittal spinal variables were normally-distributed $(p>0.05)$. Therefore, parametric analyses 272 were carried out in order to compare sagittal spinal mean angles by competition categories and 273 training workload. Pairwise comparison of means (Student t-test for independent samples) was 274 used to examine the differences between groups of training hours per year and training volume in 275 relation to sagittal spinal and pelvic disposition angles. One-Way Analysis of Variance 276 (ANOVA) was carried out to analyse sagittal spinal mean angles between competition 277 categories. Furthermore, the absolute and relative frequency of athletes in each category of spinal 
278 morphotype and pelvic disposition were also calculated. Likewise, it was also calculated the 279 absolute and relative frequency of players in each category and subcategory according to their 280 "Sagittal Integrative Morphotype".

281 The analysis was performed using SPSS version 23.0 (SPSS Inc, Chicago, IL, USA). The level

282 of significance $(\alpha)$ was set at 0.05 ; therefore, $p$ values less than 0.05 were considered to be 283 statistically significant.

284 Results

285 Sagittal thoracic and lumbar morphotype \& pelvic disposition

286 The means and standard deviations values for spinal curves in each of the three positions and for

287 values of pelvic disposition are shown in table 5 according to competition categories and training

288 workload.

$289 * * *$ Insert table 5 here ${ }^{* * *}$

290 As it can be observed, there were significant differences across competition categories for the

291 thoracic curve in MFT. Concretely, it was found that U16 had a significant higher dorsal

292 kyphosis than $\mathrm{U} 11\left(\mathrm{~F}_{(2,71)}=3.459 ; p=0.037 ; \eta^{2}=0.09\right)$ in MFT. In contrast, U11 presented a

293

294

295

296

297

298

299

300

301

302 greater posterior pelvic tilt than $\mathrm{U} 16\left(\mathrm{~F}_{(2,71)}=4.082 ; p=0.021 ; \eta^{2}=0.1\right)$.

With regard to "training hours per year", it was found that those who trained $>160$ hours per year had higher dorsal kyphosis in SP $\left(\mathrm{t}_{(72)}=-2.051 ; p=0.044 ; d=0.63\right)$ and in $\mathrm{SSP}\left(\mathrm{t}_{(72)}=-2.694 ; p\right.$ $=0.009 ; d=0.48)$ than those who had less training load per year. In addition, it was observed a tendency toward signification for dorsal and lumbar kyphosis in MFT ( $p=0.065$ and $p=0.067$, respectively), presenting a greater dorsal kyphosis and a less pronounced lumbar kyphosis those who trained $>160$ hours per year. Nevertheless, no statistically significant differences were found when spinal curves in each position were analysed depending on the "training volume".

Taking into account the references of normality presented in table 2 , it is observed that $\mathrm{IH}$

303 players have an angular mean above normal in SSP for both the dorsal and lumbar curvature.

304 Table 6 shows the percentage and frequency of athletes within each category by assessment position for each spinal curvature and for pelvic disposition.

305 *** Insert table 6 here***

306 As for the relaxed SP, the results showed that $60.8 \%$ of the athletes presented normal kyphosis,

307

308 $37.8 \%$ had hyperkyphosis, and $1.4 \%$ had rectification (hypo- or reduced kyphosis) for the

309 thoracic curve, while $89.2 \%$ of the athletes were classified as normal, $1.4 \%$ had hyperlordosis and $9.5 \%$ presented rectification (hypo- or reduced lordosis) for the lumbar curvature. With regard to the SSP, the results showed that $35.1 \%$ of the athletes presented normal kyphosis, $64.9 \%$ had hyperkyphosis, and $1.4 \%$ had hypokyphosis for the thoracic curve. On the other hand, $31.1 \%$ were within normal ranges, $68.9 \%$ had hyperkyphosis and $0 \%$ presented hypokyphosis for

314 In a MFT, $74.3 \%$ of the athletes presented normal kyphosis, $17.6 \%$ had hyperkyphosis, and $8.1 \%$

315 had hypokyphosis for the thoracic curve. As for the lumbar curvature, the results showed that

$31655.4 \%$ had a normal lumbar curve, $44.6 \%$ had hyperkyphosis and $0 \%$ presented hypokyphosis.

317 When the L-H fx was evaluated, the results showed that only $16.2 \%$ of the athletes were

318 classified as normal, whereas most of IH players were categorized in a posterior pelvic tilt

319 (41.9\% with a mild posterior pelvic tilt and $41.9 \%$ with a moderate posterior pelvic tilt). 


\section{Sagittal Integrative Spinal Morphotype}

321 The values for the sagittal morphotype of the spine integrating the three assessed positions (SP,

322 SSP and MFT) can be observed in tables 6 and 7. Both tables show the frequency of IH players

323 in each category according to the integrative diagnosis of the sagittal spinal morphotype

324 (Santonja, 1996).

325 With regard to sagittal thoracic morphotype, only 13 IH players presented "Normal Morphotype"

326 with a normal kyphosis in the 3 measurement positions. Thirty-one IH players adopted a normal

327 kyphosis in a relaxed SP, but with an increased kyphosis (hyperkyphosis) in a SSP (static) or in

328 MTF (dynamic), and they were diagnosed with "Functional Thoracic Hyperkyphosis". Twenty-

329 eight IH players were diagnosed with "Hyperkyphosis" because they adopted a hyperkyphotic

330 curvature in a SP and in a SSP (static) or in MFT (dynamic). When a player presented a

331 hyperkyphotic morphotype in the three positions he was categorized as "Total Hyperkyphosis".

332 Only one IH player was diagnosed with "Hypomobile Kyphosis" (adopted a normal kyphosis in

333 a relaxed SP and in a SSP, but presented a hypokyphosis in MFT), and another player with

334 "Hypokyphosis or Hypokyphotic Attitude" (adopted a normal kyphosis in a SSP and in MFT,

335 while a hypokyphosis is presented in a relaxed SP) [Table 7].

$336 * * *$ Insert table 7 here ${ }^{* * *}$

337 With regard to the sagittal integrative lumbar morphotype (table 8), only $17 \mathrm{IH}$ players presented

338 "Normal morphotype" with a normal lumbar curvature in the three assessed positions. Forty-nine

339 IH players adopted a normal kyphosis in a relaxed SP, but with an increased kyphosis

340 (hyperkyphosis) in a SSP (static) $(\mathrm{n}=15)$ or in a MFT (dynamic) $(\mathrm{n}=4)$, or in both positions

341 (total) $(\mathrm{n}=30)$, and they were diagnosed with "Functional Lumbar Hyperkyphosis". Five IH

342 players were diagnosed with "Structured Lumbar Kyphosis" because they presented a

343 hypolordosis or kyphosis in a SP and a hyperkyphosis in a SSP and in MFT. Only two IH players

344 were diagnosed with "Hypolordosis" (with a hypolordosis in a relaxed SP, but a normal lordosis

345 in a SSP and in MFT). Finally, another IH player was diagnosed with "Lumbar Hypermobility".

346 No players presented the morphotype "Hyperlordotic Attitude" or "Structured Hyperlordosis".

$347 * * *$ Insert table 8 here ${ }^{* * *}$

348 Discussion

349 This study was undertaken to investigate the sagittal spinal curvatures of the thoracic and lumbar

350

351

352

353

354

355

356

357

358

359 spine and its relationship to training load, and to describe the "Sagittal Integrative Morphotype" in young federated IH players.

IH has specific requirements for players, which include trunk forward bending and concrete movements such as skating, generating physical needs that do not occur in other sports. These physical demands make IH players susceptible to certain postural and structural adaptations that can result in subsequent injuries and back pain. Previous studies have shown that those specific and repetitive movements and postures of each sport influence spinal curvatures (Rajabi et al., 2008; Uetake, Ohtsuki, Tanaka, \& Shindo, 1998; Wodecki, Guigui, Hanotel, Cardinne, \& Deburge, 2002) and for that reason, several studies agree on the importance of a postural initial evaluation in order to identify spinal deformities and sagittal imbalances. Sagittal curvatures are

Peer] reviewing PDF | (2019:07:39233:1:1:NEW 4 Nov 2019) 
360

361

362

363

364

365

366

367

368

369

370

371

372

373

374

375

376

377

378

379

380

381

382

383

384

385

386

387

388

389

390

391

392

393

394

395

396

397

398

geometric parameters which influence mechanical properties of the spine during compressive loading (Harrison et al., 2005; Keller et al., 2005). Sagittal alignment influences postural loading and the load balance of the intervertebral disc, therefore, abnormal spinal curvatures cause increased forces to act upon the intervertebral discs (Keller et al., 2005). Alterations in spinal curvatures may potentially influence the development of lower back pain (Harrison et al., 2005; Smith, O'Sullivan, \& Straker, 2008), which is a common pathology among athletes (Kameyama et al., 1995).

The most reliable technique to quantify kyphosis and lordosis is the conventional spinal X-ray method. There are other methods free of ionizing radiation that assess the curvatures of the spine in the sagittal plane, for instance, the inclinometer provides a non-invasive evaluation with good reproducibility, reliability and correlation with the radiographic measurement (López-Miñarro, Alacid, Ferragut, \& García-Ibarra, 2008; Sainz de Baranda et al., 2010; Sainz de Baranda et al., 2009; Sanz-Mengibar et al., 2018).

The integrative diagnosis of the sagittal morphotype of the spine was defined by Santonja (1996) and adds the assessment of the sagittal curvatures during MFT and in a SSP (Sainz de Baranda et al., 2010; Sainz de Baranda et al., 2009; Santonja, 1996; Sanz-Mengibar et al., 2018) to the classical quantification of the thoracic and lumbar curves in a relaxed standing position in order to perform a more accurate diagnosis.

\section{Reference values and categories for thoracic curvature in previous studies}

In the current study, mean thoracic curvature value was $38.5^{\circ}, 45.2^{\circ}$ and $53.7^{\circ}$ in a relaxed $\mathrm{SP}$, in a SSP and in MFT, respectively.

Wojtys et al. (2000) found similar values (a mean of $38.1^{\circ}$ ) when they studied the thoracic curve in 189 ice-hockey players (aged between 8-18 years) in a relaxed SP. In sports like basketball, handball, volleyball and female artistic gymnast, some studies have found similar or lower angular values; while other studies found higher values in swimmers, runners, tennis players, trampoline gymnasts, male artistic gymnasts, cross-country skiers, and paddlers (Table 9). On the other hand, it is interesting to note that in sports related to dancing abilities, thoracic angular values tend to be much lower than in other types of sports (Gómez Lozano, 2007; GómezLozano, Vargas-Macías, Santonja, \& Canteras-Jordana, 2013; Nilsson, Wykman, \& Leanderson, 1993).

In the current study, a mean angular value of $45.2^{\circ}$ was observed in the SSP for the thoracic curve. This mean value is lower than those observed in trampoline gymnasts (Sainz de Baranda \& Santonja, 2009; Sainz de Baranda et al., 2010) and paddlers (López-Miñarro et al., 2008). In contrast, this angular value is higher than those observed in artistic gymnasts (Sanz-Mengibar et al., 2018).

In the MFT, a mean thoracic angular value of $53.7^{\circ}$ was observed among the IH players studied in the present investigation. However, previous research has found higher values in runners, paddlers and male artistic gymnasts (López-Miñarro et al., 2008; López-Miñarro, Alacid, \& Muyor, 2009). On the other hand, similar or lower angular values for the thoracic curve were 
399

400

401

402

403

404

405

406

407

408

409

410

411

412

413

414

415

416

417

418

419

420

421

422

423

424

425

426

427

428

429

430

431

432

433

434

435

436

437

438

observed in trampoline gymnasts and female artistic gymnasts (Sainz de Baranda et al., 2009; Sanz-Mengibar et al., 2018).

*** Insert table 9 here***

When the results were analysed by "training hours per year", it was found that players who trained more than 160 hours per year presented a significantly higher dorsal kyphosis in SP and SSP and a tendency toward signification in MFT than those who had less training load.

Furthermore, it was observed that U16 had a significant higher dorsal kyphosis than U11 in MFT. In this sense, varies studies have found a relationship between sports training and variations in the sagittal spinal curvatures of adolescent athletes (Ferreira-Guedes \& AmadoJoão, 2014; Grabara, 2015; Hecimovich \& Stomski, 2016; Sainz de Baranda, Santonja, \& Rodriguez-Iniesta, 2010). Wojtys et al., (2000) reported an increase in sagittal spinal curvature in adolescents who participated in ice hockey and exceeded 400 hours of training per year. Intense physical training combined with a developing spine, where loads are transferred from the upper to the lower extremities, leads to an overload of the spinal structures that could influence the deformation of the spine.

In sports with predominance of the trunk forward bending position, like IH, skiing, canoeing, cycling or show jumping riding, it has been found a high percentage of thoracic hyperkyphotic postures (Alricsson \& Werner, 2006; Förster, Penka, Bösl, \& Schöffl, 2009; Ginés-Díaz et al., 2019; López-Miñarro et al., 2008; Rajabi et al., 2008). In contrast, repetitive back hyperextension movements or a remain trunk extension position, which are popular among rhythmic gymnasts or classical dancers tend to flatten the normal thoracic curve to a thoracic hypokyphosis (Grabara, 2015; Kums, Ereline, Gapeyeva, Pääsuke, \& Vain, 2007; Nilsson et al., 1993 ) as well as to increase the lumbar curve and generate lumbar hyperlordosis (Falter \& Hellerer, 1982).

IH is a very fast paced game, which is characterized by high intensity intermittent skating, rapid changes in velocity and duration, frequent body contact, and the execution of a wide variety of technical skills (Flik, Lyman, \& Marx, 2005; Mölsä, Kujala, Myllynen, Torstila, \& Airaksinen, 2003). IH implicates adapting the body to a hard physical effort and to the required posture for that sport. As a result, athletes commonly present postures that are related to the most common sports abilities in each discipline (Rajabi et al., 2008; Usabiaga et al., 1997). As Wojtys, AshtonMiller, Huston, \& Moga (2000) stated, specific postures and actions which take place in IH practice might modify the sagittal spinal curvatures by altering spine's exposure to certain mechanical loads during the athlete's growth. In adolescents, Ferreira-Guedes \& Amado-João (2014) note that "these biomechanical compensations may influence the growth processes and lead to the development of various postural patterns due to the immaturity of their musculoskeletal structures. At first, the postural compensations are adaptive, but later they can become permanent and even predispose young athletes to injuries". So, the results of the current study could confirm that sagittal curvatures of the spine can be modified with regular IH training as previously described in other sports (Ginés-Díaz et al., 2019; Sainz de Baranda et al., 2009; Sanz-Mengibar et al., 2018; Uetake et al., 1998). 
439 In the current study, most of IH players had normal angular values in a relaxed SP ( $\mathrm{n}=45 / 74$, $44060.8 \%)$ and in a MFT ( $n=55 / 74,74.3 \%$ ) for the thoracic curve (figure 3 ). However, in the SSP 441 there was a higher percentage of IH players with an increased thoracic curvature or

442 hyperkyphosis $(\mathrm{n}=48 / 74,64.9 \%)$.

$443 * * *$ Insert figure 3 here $* * *$

444 The percentages of normality in a relaxed SP have been greater than in previous studies. For

445

446

447

448

449

450

451

452

453

454

455

456

457

458

459

460

461

462

463

464

465

466

467

468

469

470

471

472

473

474

475

476

477 instance, Grabara (2016) found 60-70\% of hyperkyphosis in 10 basketball players who were 13 years old. Likewise, Pastor et al. (2002) found $57.1 \%$ and $46.5 \%$ of male and female young elite swimmers with hyperkyphosis. López-Miñarro et al. (2009) found $37 \%$ of young kayakers having neutral thoracic kyphosis and 63\% with hyperkyphosis, while Muyor, López-Miñarro, \& Alacid (2011) reported that $41.7 \%$ of elite cyclists showed neutral thoracic kyphosis and 58.3\% presented thoracic hyperkyphosis. In another study, Muyor, López-Miñarro, \& Cárceles (2011) reported that elite cyclists showed a statistically higher thoracic hyperkyphosis than non-athlete subjects. These authors justified their findings with specific sport adaptations. In this sense, Grabara \& Hadzik (2009) found that a kyphotic posture tended to be more frequent and the lordotic one less frequent in volleyball players than in untrained subjects. The authors attributed that finding to the typical volleyball posture consisting of forwarding bending with rounded back as well as the arms and shoulders protruding. Wojtys et al. (2000) reported that high-intensity training increases the risk of developing adolescent hyperkyphosis. In this sense, Alricsson \& Werner (2006) found that after 5 years of intensive training the skiers increased their thoracic kyphosis but no change in lumbar lordosis was noticed.

Other studies found lower percentages of thoracic hyperkyphosis. For instance, Muyor et al. (2013) found $37.5 \%$ and $6.2 \%$ of thoracic hyperkyphosis in 24 male and 16 female elite adolescent tennis players, respectively. López-Miñarro et al. (2008) found a $26.1 \%$ and 15\% of thoracic hyperkyphosis in 23 kayak paddlers and 20 canoe young athletes, respectively. Finally, Sanz-Mengibar et al. (2018) found 16.6\% of thoracic hyperkyphosis in 47 artistic gymnastics who competed in national and international tournaments.

As for the assessment of the spinal curvatures in other positions, Sanz-Mengibar et al. (2018) found a $37 \%$ and $79.1 \%$ of thoracic hyperkyphosis in artistic gymnastics in a MFT as well as in a SSP, respectively. López-Miñarro et al. (2008) found higher percentages of thoracic hyperkyphosis in infantile male paddlers. The results showed that $25 \%$ and $45 \%$ of kayak and canoe athletes, respectively, had thoracic hyperkyphosis in MFT. In the same study, these authors found that $82 \%$ and $95 \%$ of kayak and canoe athletes, respectively, had thoracic hyperkyphosis in a SSP.

Pastor et al. (2002) observed only $24.7 \%$ of the morphotypes within normality in swimmers, $29.4 \%$ of the morphotypes with mild kyphosis and $45.9 \%$ with moderate kyphosis. The same author performed a radiological study in the position of Sit and Reach test and observed a higher percentage of moderate and marked thoracic curves $(\mathrm{p}<0.05)$ and a significant tendency to increase the number of vertebral wedges as the value of kyphosis and age increased. In addition, 
478 these wedges were related to the dynamic thoracic kyphosis, since the swimmers with more

479 thoraco-lumbar wedges presented higher values of dynamic thoracic kyphosis $(\mathrm{p}<0.05)$.

480 In contrast, Gómez-Lozano (2007) only observed $6.1 \%$ and $3 \%$ of misaligned morphotypes in

481 classic and Spanish dancers, respectively, as only some mild hyperkyphotic attitudes were

482 diagnosed in this posture.

483 It must be pointed out that not all studies use the same spinal assessment protocol and the same 484 references to categorize sagittal spinal angular values. In this sense, Grabara (2016) established 485 that values above $35^{\circ}$ are considered thoracic hyperkyphosis, thoracic normality is considered 486 from $25^{\circ}$ to $35^{\circ}$ and thoracic hypokyphosis is accepted when the value is lower than $25^{\circ}$. Muyor 487 et al. (2013) used the references of normality proposed by Mejia, Hennrikus, Schwend, \& Emans 488 (1996) and Tüzün, Yorulmaz, Cindaş, \& Vatan (1999), where the values between $20^{\circ}$ and $45^{\circ}$ are 489 accepted as neutral thoracic kyphosis, values below $20^{\circ}$ are considered thoracic hypokyphosis, 490 and values above $45^{\circ}$ are considered thoracic hyperkyphosis. However, Pastor et al. (2002) and 491 Gómez-Lozano (2007) used the same reference values in the current study.

492 Reference values and categories of lumbar curvature

493 Regarding the lumbar curvature, in the current study mean values were $28.7^{\circ}, 20.3^{\circ}$ and $31.5^{\circ}$ in 494 a relaxed SP, in a SSP and in MFT, respectively.

495 In comparison with our results, Wojtys et al. (2000) found an average value much higher $\left(44.5^{\circ}\right)$ 496 for the lumbar curvature in a relaxed SP in 189 ice-hockey players aged from 8 to 18 years old. 497 In all the sports participants whose spinal morphotype has been assessed (Table 10), higher 498 values have been observed in this position, except in basketball players (Ferreira-Guedes \& 499 Amado-João, 2014) and in artistic gymnasts (Sanz-Mengibar et al., 2018).

500 Sainz de Baranda et al. (2009) found a mean value of $36.25+10.1^{\circ}$ with 69 competition gymnasts 501 of the Trampoline modality (35 girls and 34 boys). When the results were compared by sex, it 502 was observed a greater lumbar lordosis in girls $\left(40.31^{\circ}+10^{\circ}\right)$ than in boys $\left(32.06^{\circ}+7.7^{\circ}\right)$. 503 When Ohlén et al. (1989) assessed the spinal morphotype, it was found a mean value of $50435.6^{\circ} \pm 7.8^{\circ}$ for the lumbar curve with a Debrunner's cifometer and value of $35.2^{\circ} \pm 6.9^{\circ}$ with an 505 inclinometer in 64 artistic gymnasts. $20 \%$ of the gymnasts manifested lower back pain. When 506 values for the lumbar curve were compared between the gymnasts with pain $\left(40.6^{\circ}+7.9^{\circ}\right)$ and the 507 asymptomatic gymnasts $\left(35.4^{0}+7.2^{\circ}\right)$, it was observed that the mean lordotic value was higher in 508 gymnasts with back pain. In addition, the authors found a significant correlation between back 509 pain and a lumbar lordosis greater than $41^{\circ}$.

510 Martínez-Gallego (2004) observed mean values of $35.88^{\circ} \pm 8.69^{\circ}$ in 82 competitive rhythmic 511 gymnasts and values of $40.30^{\circ} \pm 8,98^{\circ}$ in 81 recreational rhythmics gymnasts.

512 Conesa-Ros (2015) observed mean value of $32.9^{\circ} \pm 8.5^{\circ}$ in a group of competitive aesthetic 513 gymnasts. In addition, the author observed that a lumbar lordosis tended to increase with age. 514 Thus, the group of competitive aesthetic gymnasts under 11 years old had a lumbar value of $51528^{\circ} \pm 6.8^{\circ}$ and the group over 15 years old had a mean lumbar value of $36.4^{\circ} \pm 9.2^{\circ}$. The group of 516 competitive rhythmic gymnasts under 11 had a mean lumbar lordosis of $33.8^{\circ} \pm 9.4^{\circ}$, while the 517 group over 15 years old had a mean lumbar value of $39.2^{\circ} \pm 8.6^{\circ}$. 
518 This evolution of lordosis with age has also been found in previous studies carried out with 519 school-aged children (Cil et al., 2005; Murray \& Bulstrode, 1996; Voutsinas \& MacEwen, 1986).

520 With regard to the lumbar curvature in a SSP, the results of the current study showed a mean 521 value of $20.3^{\circ}$. There are few studies which have assessed the sagittal spinal curvatures in a SSP

522 (Conesa-Ros, 2015; Gómez-Lozano, 2007; López-Miñarro et al., 2008; Martínez-Gallego, 2004;

523 Sainz de Baranda et al., 2009; Sanz-Mengibar et al., 2018).

524 Sainz de Baranda et al. (2009) observed a mean value of $17.4^{\circ} \pm 9.6^{\circ}$ for the lumbar curve in

525 gymnasts of the Trampoline modality. When the results were compared by sex, a significantly

526 greater lumbar kyphosis was observed in males $\left(21^{\circ} \pm 7.9^{\circ}\right)$ than in female gymnasts $\left(14^{\circ} \pm 10^{\circ}\right)[\mathrm{p}$ $527<0.004]$.

528 Conesa-Ros (2015) and Martínez-Gallego (2004) showed how sports practice can influence or

529 can be related to a higher angular value for the lumbar curve in their studies with aesthetic and

530 rhythmic gymnasts. In this sense, both rhythmic and aesthetic gymnasts $\left(16.7^{\circ} \pm 6.6^{\circ}\right.$ and

$53115.9^{\circ} \pm 8.1^{\circ}$, respectively) had a significantly greater lumbar kyphosis than the control group

$532\left(13.8^{\circ} \pm 7.7^{\circ}\right)[\mathrm{p}=0.033]$.

533 In the same way, Martínez-Gallego (2004) also observed a greater lumbar kyphosis in a SSP in

534 the rhythmic gymnast's groups, either recreational $\left(16.24^{\circ} \pm 7.29^{\circ}\right)$ or competitive $\left(16,8^{\circ} \pm 6.55^{\circ}\right)$,

535 when compared with the control group $\left(13.81^{\circ} \pm 7.72^{\circ}\right)$.

536 The incorrect alignment of the lumbar spine found in the SSP in the three modalities of

537 gymnastics could be due to repetitive hyperflexions and hyperextensions of the trunk which are

538 performed in gymnastics. Thus, these movements could come to a hypermobile lumbar curve.

539 López-Miñarro et al. (2008) found angular lumbar values lower than $20^{\circ}$ in 43 infantile paddlers

540 (23 kayakers and 20 canoeists), and no significant differences were found between kayakers and

541 canoeists. Likewise, when López-Miñarro et al. (2008) (2014) assessed the sagittal spinal curves

542 of 130 canoeists (aged from 15 to 20 years old), the authors found values lower than $20^{\circ}$ for the

543 lumbar curvature, with no significant differences regarding gender.

544 Sanz-Mengibar et al. (2018) observed mean value of $15.62^{\circ} \pm 6.41^{\circ}$ for the lumbar curve in their

545 study with gymnasts of the artistic modality, and no significant differences between boys

$546\left(15.52^{\circ}+6.92^{\circ}\right)$ and girls $\left(15.71^{\circ}+6.02^{\circ}\right)$ were found. However, Gómez-Lozano (2007) observed a

547 lower mean value of lumbar kyphosis among classic dancers $\left(8.33^{\circ} \pm 6.44^{\circ}\right)$ in a SSP.

548 With regard to the lumbar curvature in the MFT, the results of the current study showed a mean

549 value of $31.5^{\circ}$. In trampoline gymnasts, runners and paddlers were found similar or lower values

550 (Andújar, Medina, \& Iniesta, 2010; López-Miñarro et al., 2009; Sainz de Baranda et al., 2009;

551 Sanz-Mengibar et al., 2018).

$552 * * *$ Insert table 10 here***

553 Figure 4 indicates that most of the athletes had normal angular values for the lumbar curvature in

554 a relaxed SP $(n=66 / 74,89.2 \%)$ and in a MFT $(n=41 / 74,55.4 \%)$. However, there is a higher

555 percentage of IH players with increased angular values or hyperkyphosis $(n=51 / 74,68.9 \%)$ in a

556 SSP.

$557 * * *$ Insert figure 4 here $* * *$ 
558 In the current study, it was found a 9.5\% of lumbar rectification and $1.4 \%$ of lumbar 559 hyperlordosis in the relaxed SP. In contrast, Pastor et al. (2002) found higher percentages of 560 lumbar hyperlordosis in young elite swimmers ( $7.1 \%$ in males and $32.3 \%$ in females). López561 Miñarro et al. (2008) reported that $8.7 \%$ of 23 kayakers and $10 \%$ of 178 canoeists had lumbar 562 rectification. Grabara (2016b) found $50 \%$ of hypolordosis and $10 \%$ of hyperlordosis in 10 563 basketball players aged from 13 years old. Recently, Sanz-Mengibar et al. (2018) observed 564 lumbar hyperlordosis in $12.5 \%$ of 47 artistic gymnastics.

565 It was also found that $68.9 \%$ and $44.6 \%$ of the IH players had lumbar hyperkyphosis in a SSP 566 and in a MFT, respectively.

567 Some previous studies found higher percentages of hyperkyphosis for the lumbar curvature in 568 these positions, possibly due to the practice of the sport in a sitting position or the repetition of 569 technical gestures with a maximal ROM in the lumbar spine and lower limb. In this sense, 570 López-Miñarro et al. (2008) reported that around 90\% of paddlers had lumbar hyperkyphosis in 571 MFT. In addition, these authors found lumbar hyperkyphosis in around $75 \%$ of kayak and canoe 572 athletes in a SSP.

573 In contrast, Sanz-Mengibar et al. (2018) found 39\% of lumbar hyperkyphosis in both MTF and 574 in a SSP among artistic gymnasts.

575 It must be pointed out that not all studies use the same spinal assessment protocol and the same 576 references to categorize sagittal spinal angular values. In this sense, for the relaxed SP, Grabara 577 (2016b) established that values above $35^{\circ}$ are considered lumbar hyperlordosis, a neutral lumbar 578 spine is considered from $25^{\circ}$ to $35^{\circ}$ and lumbar hypolordosis is accepted when the value is lower 579 than $25^{\circ}$. Muyor et al. (2013) used the references of normality proposed by Tüzün et al. (1999), 580 where the values between $20^{\circ}$ and $40^{\circ}$ are accepted as a neutral lumbar spine, values below $20^{\circ}$

581

582

583

584

585

586

587

588

589

590

591

592

593

594

595

596 are considered as an hypolordotic lumbar spine, and values above $40^{\circ}$ are considered hyperlordosis.

With respect to the MFT, Pastor et al. (2002) established that values below $22^{\circ}$ are considered as normal lumbar kyphosis and values between $22^{\circ}-29^{\circ}$ are considered as lumbar hyperkyphosis. As for the SSP, the author established that values below $<14^{\circ}$ were accepted as normal lumbar kyphosis and values between $14-21^{\circ}$ were considered lumbar hyperkyphosis.

\section{Pelvic Disposition}

The flexibility of hamstring muscles is important for the prevention of muscular and postural imbalances, for the maintenance of the full range motion in the hip flexion as well as for the optimal musculoskeletal function (Sainz de Baranda et al., 2014). Hamstrings extensibility influences pelvic posture (Congdon, Bohannon, \& Tiberio, 2005) and spinal curvatures (López-Miñarro et al., 2009). Decreased extensibility of hamstring muscles has been associated with a greater thoracic kyphosis and a higher posterior pelvic tilt when maximal trunk flexion with knees extended is performed. Consequently, an incorrect hamstrings extensibility and the constant repetition of trunk hyperflexion and hyperextension due to the sports practice could increase intervertebral stress (Beach, Parkinson, Stothart, \& Callaghan, 
597

598

599

600

601

602

603

604

605

606

607

608

609

610

611

612

613

614

615

616

617

618

619

620

621

622

623

624

625

626

627

628

629

630

631

632

633

634

635

2005) as well as thoracic and lumbar intradiscal pressure (Polga et al., 2004; Wilke, Neef, Caimi, Hoogland, \& Claes, 1999), predisposing subjects to spinal disorders (McGill, 2002).

The results of the current study suggest that a hamstring-specific extensibility program is necessary for this group of IH players, especially among the youngest (U11) since they showed a greater posterior pelvic tilt than U16. Only $16.2 \%$ of the IH players showed normal values for the L-H fx angle.

In fact, a high percentage of IH players showed decreased hamstrings flexibility, since $41.9 \%$ of IH players presented a mild and a moderate posterior pelvic tilt. This lack of flexibility may influence pelvic and spinal postures in a maximum flexion of the trunk, which is a very common position adopted in the IH techniques. Thus, prior evaluation of hamstring flexibility is recommended to point out specific and individualized preventive programmes in order to prevent spinal problems.

\section{Sagittal Integrative Spinal Morphotype}

This is the first study in which 3 different positions are combined for the diagnosis of the sagittal spine in young IH players. There are few studies that perform the "Sagittal Integrative Morphotype" assessment (Collazo, 2015; Ginés-Díaz et al., 2019; Sanz-Mengibar et al., 2018), so the comparison with existing literature is difficult.

On the one hand, for the thoracic curve, the most frequent diagnosis is "Functional Hypekyphosis" (41.9\%), which means that they would mainly need to improve their spinal alignment in a SSP and in MFT. Concretely, most of them presented a "Static Functional Hyperkyphosis" (17.6\%) or a "Total Functional Hyperkyphosis" (18.9\%). On the other hand, 28 IH players (37.9\%) were diagnosed with "Hyperkyphosis". To be more specific, $16.2 \%$ of them had "Total Hyperkyphosis" and 12.2\% presented "Static Hyperkyphosis". These diagnoses are in line with those found in young riders (mean age: 14.55 years), artistic gymnasts (mean age: 15.02 years) and schoolchildren (mean age: 10.55 years) in which the most common thoracic sagittal integral morphotype was "Functional Thoracic Hyperkyphosis" (40\%, 62.5\% and 36.8\%, respectively) (Collazo, 2015; Ginés-Díaz et al., 2019; Sanz-Mengibar et al., 2018).Since 29.8\% of IH players were diagnosed with "Static Hyperkyphosis" and "Static Functional Fyperkyphosis", these players would also need to improve their posture in a SSP and in the relaxed SP, in fact, these results might be associated with poor postural hygiene while sitting. As for the lumbar curvature, most of IH players ( $n=49 ; 66.2 \%)$ were diagnosed with "Functional Lumbar Hyperkyphosis". Specifically, $20.3 \%$ of players had "Static Functional Lumbar Hyperkyphosis" and 40.5\% presented a "Total Functional Lumbar Hyperkyphosis". Again, these results coincide with previous studies (riders: 40\%, artistic gymnasts: 39.58\%, schoolchildren: 82.4\%) (Collazo, 2015; Ginés-Díaz et al., 2019; Sanz-Mengibar et al., 2018).

In this sense, as Purcell \& Micheli (2009) stated, repetitive flexo-extension and torsion movements because of technical-tactical actions in IH can result in overuse injuries to the spine. In fact, these repetitive movements with an imbalanced spinal posture (e.g. hyperkyphotic position with the trunk bent forward) are particularly worrisome in young IH players. Therefore, 
636 the position of the lumbar spine while sitting or trunk forward bending should be trained for a

637 better alignment through pelvic proprioceptive exercises or trunk muscles strengthening.

638 Furthermore, it is important to highlight the fact that $6.8 \%$ of the IH players were diagnosed with

639 "Structured Lumbar Kyphosis". In this sense, it has to be pointed out that the high prevalence of

640 posterior pelvic tilt found among players could have led to a misaligned lumbar spine during

641 maximum flexion of the trunk probably due to the hamstrings tightness that can make the pelvis

642 lose its horizontality and adopt a posterior pelvic tilt (López-Miñarro, Muyor, Belmonte, \&

643 Alacid, 2012; Santonja et al., 1994). Since the trunk forward bending while standing is the basic

644 posture in $\mathrm{IH}$, the players should train their hamstrings flexibility in order to keep a neutral

645 lumbar spine when their trunk is bent forward. In addition, good pelvic proprioception would be

646 necessary to keep a neutral pelvic tilt while IH players have to stay in constant quadruple flexion

647 (ankle, knee, hip and trunk).It is important to note that if sagittal spinal assessment had been only

648 carried out in standing position, the results of this study would have shown that most of $\mathrm{IH}$

649 players were within the normal ranges for both curves $(60.8 \%$ of the athletes presented normal

650 kyphosis and the $89.2 \%$ of the athletes presented normal lordosis in the standing position).

651 However, taking into account the "Sagittal Integrative Morphotype" it was determined that IH

652 players had a misaligned sagittal spine. These results show how important is to include the

653 assessment of the three positions as part of the protocol in order to define "Sagittal Integrative

654 Morphotype" and so as to establish a correct diagnostic (Sanz-Mengibar et al., 2018). Therefore,

655 an incorrect sagittal spinal assessment leads to misclassification of the athletes' morphotypes,

656 generating negative consequences, not only in terms of deformity and pain but also in preventive

657 and rehabilitative terms (Ginés-Díaz et al., 2019).

658 Some limitations of the present study must be reported. The age distribution of the participants

659 was relatively limited and the sample size was relatively small. Furthermore, only male IH

660 players were assessed. In addition, patients with radiographic evidence deformity may present a

661 normal spinal morphotype. Future studies which include a larger sample should investigate the

662 association between sagittal spinal morphotype and back pain or the ratio of injury. Furthermore,

663 prospective investigations in order to study how sagittal spinal curves develop with age and

664 practice are needed.

\section{Conclusions}

666 Federative IH practice seems to cause specific adaptations in spinal sagittal morphotype in young

667 players. The findings reported in the present study suggest an association between exposure to

$668 \mathrm{IH}$ athletic training, age and increased thoracic kyphosis.

669 The most prevalent sagittal spinal misalignments in young federated male IH players were the

670 thoracic hyperkyphosis (64.9\%) and the lumbar hyperkyphosis (68.9\%) in a SSP and the lumbar

671 hyperkyphosis (44.6\%) in a MFT.

672 However, taking into account the "Sagittal Integrative Morphotype" only 13 (17.6\%) IH players

673 presented "Normal Morphotype" with a normal thoracic kyphosis in the three measured

674 positions. While only 17 (23\%) IH players presented "Normal Lumbar Morphotype" with a

675 normal lumbar curvature in the three assessed positions. 
676 For the thoracic curvature, 18.9\% of the IH players presented "Total Functional Hyperkyphosis",

$67717.6 \%$ of the players presented a "Static Functional Hyperkyphosis" and 16.2\% of the players

678 had a "Total Hyperkyphosis". Whereas for the lumbar curvature a $40.5 \%$ of the players presented

679 "Total Functional Hyperkyphosis" and the $20.3 \%$ of players were diagnosed with "Static

680 Functional Hyperkyphosis". Furthermore, only $16.2 \%$ of IH players showed normal pelvic titl.

681 Clinical implications

682 It is important to assess the "Sagittal Integrative Spinal Morphotype" in sports for the pre-

683 emptive care of spinal deformities from the earliest stages. The assessment of sagittal spinal

684 curvatures in the three described positions gives a new perspective for the diagnosis of sagittal

685 spinal morphotype, which may reduce the number of players wrongly classified as normal. It is

686 important to note that the protocol is easy to apply due to the low-cost instruments used and it

687 only requires an examiner.

688 Exercise programmes to prevent or rehabilitate these imbalances in young IH players are needed.

689 Pelvic proprioceptive exercises, trunk muscles strengthening, and flexibility training could be

690 included as a part of preventive programs. This manuscript creates a paradigm for future studies

691 about associated risk factors to develop unbalanced sagittal spines in IH players.

692 References

693 Aalto, T. J., Airaksinen, O., Härkönen, T. M., \& Arokoski, J. P. (2005). Effect of passive stretch

694 on reproducibility of hip range of motion measurements. Arch Phys Med Rehab, 86(3), 549-57.

695 https://doi.org/10.1016/j.apmr.2004.04.041

696 Ackland, T. R., Elliott, B., \& Bloomfield, J. (2009). A Applied Anatomy and Biomechanics in

697 Sport. Human Kinetics.

698 Alricsson, M., \& Werner, S. (2006). Young elite cross-country skiers and low back pain-A 5-

699 year study. Phys Ther Sport, 7(4), 181-4. https://doi.org/10.1016/j.ptsp.2006.06.003

700 Alricsson, M., Björklund, G., Cronholm, M., Olsson, O., Viklund, P., \& Svantesson, U. (2016).

701 Spinal alignment, mobility of the hip and thoracic spine and prevalence of low back pain in

702 young elite cross-country skiers. J Exerc Rehabil, 12(1), 21-8.

703 https://doi.org/10.12965/jer.150255

704 Ayala, F., Sainz de Baranda, P., Cejudo, A., \& Santonja, F. (2013). Pruebas angulares de

705 estimación de la flexibilidad isquiosural: Descripción de los procedimientos exploratorios y

706 valores de referencia. Revista Andaluza de Medicina Del Deporte, 6(3), 120-8.

707 https://doi.org/10.1016/S1888-7546(13)70046-7

708 Beach, T. A. C., Parkinson, R. J., Stothart, J. P., \& Callaghan, J. P. (2005). Effects of prolonged

709 sitting on the passive flexion stiffness of the in vivo lumbar spine. Spine J, 5(2), 145-54.

710 https://doi.org/10.1016/j.spinee.2004.07.036 
711 Betsch, M., Furian, T., Quack, V., Rath, B., Wild, M., \& Rapp, W. (2015). Effects of Athletic

712 Training on the Spinal Curvature in Child Athletes. Res Sports Med, 23(2), 190-202.

713 https://doi.org/10.1080/15438627.2015.1005297

714 Callaghan, J. P., \& McGill, S. M. (2001). Intervertebral disc herniation: Studies on a porcine

715 model exposed to highly repetitive flexion/extension motion with compressive force. Clin

716 Biomech, 16(1), 28-37.

717 Cejudo, A. (2015). Deporte y Flexibilidad: Rendimiento Deportivo sin Riesgo de Lesión

718 (Doctoral Thesis). Universidad de Murcia, Murcia.

719 Christie, H. J., Kumar, S., \& Warren, S. A. (1995). Postural aberrations in low back pain. Arch

720 Phys Med Rehab, 76(3), 218-24.

721 Cil, A., Yazici, M., Uzumcugil, A., Kandemir, U., Alanay, A., Alanay, Y., ... Surat, A. (2005).

722 The Evolution of Sagittal Segmental Alignment of the Spine During Childhood. Spine, 30(1),

723 93-100 https://doi.org/10.1097/01.brs.0000149074.21550.32

724 Collazo, M. (2015). Morfotipos Sagitales del Raquis en Población Escolar en la Región de

725 Murcia (Doctoral Thesis). Universidad de Murcia, Murcia.

726 Conesa Ros, E. (2015). Valoración de la movilidad de la columna en el plano sagital y

727 extensibilidad de la musculatura isquiosural en gimnasia estética de grupo (Doctoral Thesis).

728 Universidad de Murcia, Murcia.

729 Congdon, R., Bohannon, R., \& Tiberio, D. (2005). Intrinsic and imposed hamstring length

730 influence posterior pelvic rotation during hip flexion. Clin Biomech, 20(9), 947-51.

731 https://doi.org/10.1016/j.clinbiomech.2005.03.011

732 Falter, E., \& Hellerer, O. (1982). High performance gymnasts during the period of growth.

733 Morphologia medica, 2(1), 39-44.

734 Ferreira-Guedes, P., \& Amado-João, S. M. (2014). Postural Characterization of Adolescent

735 Federation Basketball Players. J Phys Act Health, 11(7), 1401-7.

736 https://doi.org/10.1123/jpah.2012-0489

737 Flik, K., Lyman, S., \& Marx, R. G. (2005). American Collegiate Men’s Ice Hockey: An Analysis

738 of Injuries. Am J Sports Med, 33(2), 183-9. https://doi.org/10.1177/0363546504267349

739 Förster, R., Penka, G., Bösl, T., \& Schöffl, V. R. (2009). Climber's back-Form and mobility of

740 the thoracolumbar spine leading to postural adaptations in male high ability rock climbers. Int $J$

741 Sports Med, 30(1), 53-9. https://doi.org/10.1055/s-2008-1038762 
742 Ginés-Díaz, A., Martínez-Romero, M. T., Cejudo, A., Aparicio-Sarmiento, A., \& Sainz de

743 Baranda, P. (2019). Sagittal Spinal Morphotype Assessment in Dressage and Show Jumping

744 Riders. J Sport Rehabil, (Ahead of Print), 1-8. https://doi.org/10.1123/jsr.2018-0247

745 Gómez Lozano, S. (2007). Estudio sagital del raquis en bailarinas de danza clásica y danza

746 española (Doctoral Thesis). Universidad de Murcia, Murcia.

747 Gómez-Lozano, S., Vargas-Macías, A., Santonja, F., \& Canteras-Jordana, M. (2013). Estudio

748 descriptivo del morfotipo raquídeo sagital en bailarinas de flamenco. Revista Del Centro de

749 Investigación Flamenco Telethusa, 6(7), 19-28.

750 Grabara, M. (2015). Comparison of posture among adolescent male volleyball players and non-

751 athletes. Biol Sport, 32(1), 79-85. https://doi.org/10.5604/20831862.1127286

752 Grabara, M. (2016a). Could hatha yoga be a health-related physical activity? Biomedical Human 753 Kinetics, 8(1), 10-6.

754 Grabara, M. (2016b). Sagittal spinal curvatures in adolescent male basketball players and non-

755 training individuals - a two-year study. Sci Sport, 31(5), e147-53.

756 https://doi.org/10.1016/j.scispo.2016.01.010

757 Grabara, M. (2012). Body posture of young female basketball players. Biomedical Human

758 Kinetics, 4, 76-81. https://doi.org/10.2478/v10101-012-0014-0

759 Grabara, M. (2014a). A comparison of the posture between young female handball players and

760 non-training peers. J Back Musculoskelet, 27(1), 85-92. https://doi.org/10.3233/BMR-130423

761 Grabara, M. (2014b). Anteroposterior curvatures of the spine in adolescent athletes. J Back

762 Musculoskelet, 27(4), 513-9. https://doi.org/10.3233/BMR-140475

763 Grabara, M., \& Hadzik, A. (2009). Postural variables in girls practicing volleyball. Biomedical

764 Human Kinetics, 1, 67-71.

765 Green, J. P., Grenier, S. G., \& McGill, S. M. (2002). Low-back stiffness is altered with warm-up 766 and bench rest: Implications for athletes. Med Sci Sport Exer, 34(7), 1076-81.

767 https://doi.org/10.1097/00005768-200207000-00004

768 Harrison, D. E., Colloca, C. J., Harrison, D. D., Janik, T. J., Haas, J. W., \& Keller, T. S. (2005).

769 Anterior thoracic posture increases thoracolumbar disc loading. Eur Spine J, 14(3), 234-42.

770 https://doi.org/10.1007/s00586-004-0734-0 
771 Hecimovich, M. D., \& Stomski, N. J. (2016). Lumbar Sagittal Plane Spinal Curvature and

772 Junior-Level Cricket Players. Int J Athl Ther Trai, 21(2), 47-52.

773 https://doi.org/10.1123/ijatt.2015-0028

774 Jackson, M., Solomonow, M., Zhou, B., Baratta, R. V., \& Harris, M. (2001). Multifidus EMG

775 and tension-relaxation recovery after prolonged static lumbar flexion. Spine, 26(7), 715-23.

776 Kameyama, T., Hashizume, Y., Ando, T., Takahashi, A., Yanagi, T., \& Mizuno, J. (1995).

777 Spinal cord morphology and pathology in ossification of the posterior longitudinal ligament.

778 Brain, 118(1), 263-78. https://doi.org/10.1093/brain/118.1.263

779 Katz, D. A., \& Scerpella, T. A. (2003). Anterior and middle column thoracolumbar spine injuries

780 in young female gymnasts. Report of seven cases and review of the literature. Am J Sports Med,

781 31(4), 611-6. https://doi.org/10.1177/03635465030310042301

782 Keller, T. S., Colloca, C. J., Harrison, D. E., Harrison, D. D., \& Janik, T. J. (2005). Influence of

783 spine morphology on intervertebral disc loads and stresses in asymptomatic adults: Implications

784 for the ideal spine. Spine J, 5(3), 297-309. https://doi.org/10.1016/j.spinee.2004.10.050

785 Kujala, U. M., Taimela, S., Oksanen, A., \& Salminen, J. J. (1997). Lumbar Mobility and Low

786 Back Pain During Adolescence: A Longitudinal Three-Year Follow-up Study in Athletes and

787 Controls. Am J Sports Med, 25(3), 363-8. https://doi.org/10.1177/036354659702500316

788 Kums, T., Ereline, J., Gapeyeva, H., Pääsuke, M., \& Vain, A. (2007). Spinal curvature and trunk

789 muscle tone in rhythmic gymnasts and untrained girls. J Back Musculoskelet, 20(2-3), 87-95.

790 https://doi.org/10.3233/BMR-2007-202-306

791 Lichota, M., Plandowska, M., \& Mil, P. (2011). The shape of anterior-posterior curvatures of the 792 spine in athletes practising selected sports. Polish Journal of Sport and Tourism, 18(2), 112-6.

793 López-Miñarro, P. A., Alacid, F., Ferragut, C., \& García-Ibarra, A. (2008). Valoración y

794 comparación de la disposición sagital del raquis entre canoístas y kayakistas de categoría infantil.

795 Cultura_Ciencia_Deporte [CCD], 3(9), 171-6. https://doi.org/10.12800/ccd.v3i9.164

796 López-Miñarro, P. A., Alacid, F., \& Muyor, J. M. (2009). Comparación del morfotipo raquídeo y 797 extensibilidad isquiosural entre piragüistas y corredores. Rev Int Med Cienc Act, 9(36), 379-92.

798 López-Miñarro, P. A., Muyor, J. M., Belmonte, F., \& Alacid, F. (2012). Acute Effects of

799 Hamstring Stretching on Sagittal Spinal Curvatures and Pelvic Tilt. J Hum Kinet, 31, 69-78.

800 https://doi.org/10.2478/v10078-012-0007-7 
801 López-Miñarro, P. A., Sainz de Baranda, P., Rodríguez-García, P. L., \& Ortega, E. (2007). A 802 comparison of the spine posture among several sit-and-reach test protocols. J Sci Med Sport, 803 10(6), 456-62. https://doi.org/10.1016/j.jsams.2006.10.003

804 Martínez-Gallego, F. M. (2004). Disposición del plano sagital y extensibilidad isquiosural en 805 gimnasia rítmica deportiva (Doctoral Thesis). Universidad de Murcia, Murcia.

806 Martínez-Gallego, F., \& Rodríguez-García, P. L. (2005). Metodología para una Gimnasia 807 Rítmica Saludable. Madrid, Spain: Consejo Superior de Deportes.

808 Mayer, T. G., Tencer, A. F., Kristoferson, S., \& Mooney, V. (1984). Use of noninvasive 809 techniques for quantification of spinal range-of-motion in normal subjects and chronic low-back 810 dysfunction patients. Spine, 9(6), 588-95.

811 McGill, S. (2002). Low Back Disorders. Evidence-Based Prevention and Rehabilitation (Third 812 Edition). University of Waterloo, Canadá: Human Kinetics.

813 Mejia, E. A., Hennrikus, W. L., Schwend, R. M., \& Emans, J. B. (1996). A Prospective 814 Evaluation of Idiopathic Left Thoracic Scoliosis with Magnetic Resonance Imaging. J Pediatr 815 Orthoped, 16(3), 354-8.

816 Micheli, L. J., \& Trepman, E. (1990). Spinal deformities, En: F.J. Torg, R.P. Welsh, y R.J.

817 Shephard (eds.). In Current therapy in sports medicine (II, pp. 335-340). Philadelphia, USA:

818 PA: E. C. Decker.

819 Mölsä, J., Kujala, U., Myllynen, P., Torstila, I., \& Airaksinen, O. (2003). Injuries to the Upper

820 Extremity in Ice Hockey: Analysis of a Series of 760 Injuries. Am J Sports Med, 31(5), 751-7.

821 https://doi.org/10.1177/03635465030310051901

822 Murray, D. W., \& Bulstrode, C. J. (1996). The development of adolescent idiopathic scoliosis.

823 Eur Spine J, 5(4), 251-7. https://doi.org/10.1007/BF00301328

824 Muyor, J. M., López-Miñarro, P. A., \& Alacid, F. (2011). Spinal Posture of Thoracic and 825 Lumbar Spine and Pelvic Tilt in Highly Trained Cyclists. J Sports Sci Med, 10(2), 355-61.

826 Muyor, J. M., Sánchez-Sánchez, E., Sanz-Rivas, D., \& López-Miñarro, P. A. (2013). Sagittal

827 Spinal Morphology in Highly Trained Adolescent Tennis Players. J Sports Sci Med, 12(3), 58882893.

829 Muyor, J. M., López-Miñarro, P. A., \& Cárceles, F. A. (2011). Comparación de la disposición 830 sagital del raquis lumbar entre ciclistas de élite y sedentarios. Cultura_Ciencia_Deporte [CCD], 831 6(16), 37-43. https://doi.org/10.12800/ccd.v6i16.29 
832 Nilsson, C., Wykman, A., \& Leanderson, J. (1993). Spinal sagittal mobility and joint laxity in 833 young ballet dancers. Knee Surg Sport Tr A, 1(3), 206-8. https://doi.org/10.1007/BF01560208

834 Norkin, C. C., \& White, D. J. (1995). Measurement of Joint Motion: A Guide To Goniometry 835 (II). Philadelphia, USA: F.A. Davis.

836 Ogurkowska, M. B., \& Kawałek, K. (2017). Evaluation of functional and structural changes 837 affecting the lumbar spine in professional field hockey players. Acta Bioeng Biomech, 19(2).

838 Ohlén, G., Wredmark, T., \& Spangfort, E. (1989). Spinal sagittal configuration and mobility 839 related to low-back pain in the female gymnast. Spine, 14(8), 847-50.

840 Pastor, A., Santonja, F., Ferrer, V., Domínguez, F., \& Canteras, M. (2002). Determinación del 841 morfotipo sagital de la columna de jóvenes nadadores de élite españoles. Selección, 11(4), 2688429.

843 Polga, D. J., Beaubien, B. P., Kallemeier, P. M., Schellhas, K. P., Lew, W. D., Buttermann, G.

844 R., \& Wood, K. B. (2004). Measurement of in vivo intradiscal pressure in healthy thoracic 845 intervertebral discs. Spine, 29(12), 1320-4.

846 Purcell, L., \& Micheli, L. (2009). Low Back Pain in Young Athletes. Sports Health, 1(3), 212-

847 22. https://doi.org/10.1177/1941738109334212

848 Rajabi, R., Alizadeh, M., \& Mobarakabadi, L. (2007). Comparison of thoracic kyphosis in group 849 of elite female hockey players and a group on on-athletic female subjects. 24th Universidade 850 Banhkok. FISU Conference, 9-12.

851 Rajabi, R., Doherty, P., Goodarzi, M., \& Hemayattalab, R. (2008). Comparison of thoracic 852 kyphosis in two groups of elite Greco-Roman and freestyle wrestlers and a group of non-athletic 853 participants. Brit J Sports Med, 42(3), 229-32. https://doi.org/10.1136/bjsm.2006.033639 854 Rajabi, R., Mobarakabadi, L., Alizadhen, H. M., \& Hendrick, P. (2012). Thoracic kyphosis 855 comparisons in adolescent female competitive field hockey players and untrained controls. $J$ 856 Sport Med Phys Fit, 52(5), 545-50.

857 Real Federación Española de Patinaje. (2018). Reglamentos. Reglas de juego de hockey sobre 858 patines en línea. Retrieved from http://fep.es/website/infoFep_reglamentos.asp?modalidad=18 859 Roncarati, A., \& McMullen, W. (1988). Correlates of low back pain in a general population 860 sample: A multidisciplinary perspective. J Manip and Physiol Ther, 11(3), 158-64. 
861 Sainz de Baranda, M. P., Rodríguez-García, P. L., \& Santonja, F. (2010). Efectos sobre la 862 disposición sagital del raquis de un programa de Educación Postural en Educación Física de 863 Primaria. Apunts. Educación Física y Deportes, 4(102), 16-21.

864 Sainz de Baranda, P., Ferrer, V., Martínez, L., Santonja, F., Rodríguez, P. L., Andújar, P., ... 865 García, M. J. (2001). Morfotipo del futbolista profesional. Actas del II Congreso Internacional 866 de Educación Física y Diversidad, 293-5. Murcia: Consejería de Educación y Universidades.

867 Sainz de Baranda, P., Rodríguez, P. L., Santonja, F., \& Andújar, P. (2006). La Columna

868 Vertebral del Escolar (I). Sevilla: Wanceulen Editorial Deportiva S. L.

869 Sainz de Baranda, P., Rodríguez, P. L., Santonja, F., López-Miñarro, P. A., Andújar, P., Ferrer,

870 V., \& Pastor, A. (2006). Effects of hamstring stretching exercises on the toe-touch test in

871 elementary schoolchildren. J Hum Movement Stud, 51(4), 277-89.

872 Sainz de Baranda, P., Santonja, F., \& Rodríguez-Iniesta, M. (2009). Valoración de la disposición 873 sagital del raquis en gimnastas especialistas en trampolín. Revista Internacional de Ciencias del 874 Deporte [RICYDE], 5(16), 21-33.

875 Sainz de Baranda, P., Santonja, F., \& Rodriguez-Iniesta, M. (2010). Tiempo de entrenamiento y 876 plano sagital del raquis en gimnastas de trampolin. Rev Int Med Cienc Act., 10(40), 521-36.

877 Sainz de Baranda, Pilar, Rodríguez-Iniesta, M., Ayala, F., Santonja, F., \& Cejudo, A. (2014).

878 Determination of the criterion-related validity of hip joint angle test for estimating hamstring 879 flexibility using a contemporary statistical approach. Clin J Sport Med, 24(4), 320-5.

880 https://doi.org/10.1097/JSM.0000000000000079

881 Salminen, J. J., Maki, P., Oksanen, A., \& Pentti, J. (1992). Spinal mobility and trunk muscle 882 strength in 15-year-old schoolchildren with and without low-back pain. Spine, 17(4), 405-11.

883 Salminen, J. J., Oksanen, A., Mäki, P., Pentti, J., \& Kujala, U. M. (1993). Leisure Time Physical 884 Activity in the Young. Int J Sports Med, 14(7), 406-10. https://doi.org/10.1055/s-2007-1021200 885 Santonja, F. (1996). Las desviaciones sagitales del raquis y su relación con la práctica deportiva. 886 In Escolar: Medicina y Deporte. Ferrer, V., Martínez, L. and Santonja, F. (Eds.) (pp. 251-68). 887 Albacete, Spain: Diputación Provincial de Albacete.

888 Santonja, F., Andújar, P., \& González-Moro, I. (1994). Angle lumbo-horitzontal i valoració de 889 repercussions de la síndrome d'isquiosurals curts. Apunts. Medicina de l'Esport, 31(120), 103890112. 
891 Santonja, F., Ferrer, V., \& Andújar, P. (1994). Síndrome de los isquiosurales cortos. In 22: Vol.

892 233. Cirugía menor y procedimientos en medicina de familia (pp. 1063-72).

893 Santonja, F., \& Martínez, I. (1995). Raquis y deporte ¿cuál sí y cuándo? Selección, 4(1), 28-38.

894 Santonja, F., \& Morales, P. (2008). Ejercicios de acondicionamiento muscular orientados a la

895 prevención y terapia de las patologías raquídeas (I). Plano sagital. In: Rodríguez PL. In Ejercicio

896 Físico en salas de Acondicionamiento muscular. Bases científico-médicas para una práctica

897 segura y saludable (I, pp. 241-55). Madrid, Spain: Panamericana.

898 Santonja, F., \& Pastor, A. (2000). Cifosis y Lordosis. In Cirugía Menor y Procedimientos en

899 Medicina de Familia. Arribas, J. M., Castelló, J. R., Rodríguez-Pata, N., Santonja, F. and

900 Plazas-Andreu, N. (Eds.) (2nd Ed, Vol. 1, pp. 1049-61). Madrid, Spain: Jarpyo.

901 Sanz-Mengibar, J. M., Sainz-de-Baranda, P., \& Santonja-Medina, F. (2018). Training intensity

902 and sagittal curvature of the spine in male and female artistic gymnasts. J Sports Med Phys Fit,

903 58(4), 465-71. https://doi.org/10.23736/S0022-4707.17.06880-3

904 Saur, P. M. M., Ensink, F.-B. M., Frese, K., Seeger, D., \& Hildebrandt, J. (1996). Lumbar Range

905 of Motion: Reliability and Validity of the Inclinometer Technique in the Clinical Measurement

906 of Trunk Flexibility. Spine, 21(11), 1332-8.

907 Simunic, D. I., Broom, N. D., \& Robertson, P. A. (2001). Biomechanical factors influencing

908 nuclear disruption of the intervertebral disc. Spine, 26(11), 1223-30.

909 Smith, A., O’Sullivan, P., \& Straker, L. (2008). Classification of Sagittal Thoraco-Lumbo-Pelvic

910 Alignment of the Adolescent Spine in Standing and Its Relationship to Low Back Pain. Spine,

911 33(19), 2101-7. https://doi.org/10.1097/BRS.0b013e31817ec3b0

912 Solomonow, M., Zhou, B. H., Baratta, R. V., Lu, Y., \& Harris, M. (1999). Biomechanics of

913 increased exposure to lumbar injury caused by cyclic loading: Part 1. Loss of reflexive muscular

914 stabilization. Spine, 24(23), 2426-34. https://doi.org/10.1097/00007632-199912010-00003

915 Swärd, L., Hellstrom, M., Jacobsson, B., \& Pëterson, L. (1990). Back pain and radiologic

916 changes in the thoraco-lumbar spine of athletes. Spine, 15(2), 124-9.

917 Tüzün, Ç., Yorulmaz, İ., Cindaş, A., \& Vatan, S. (1999). Low Back Pain and Posture. Clin

918 Rheumatol, 18(4), 308-12. https://doi.org/10.1007/s100670050107

919 Uetake, T., Ohtsuki, F., Tanaka, H., \& Shindo, M. (1998). The vertebral curvature of sportsmen.

$920 J$ Sports Sci, 16(7), 621-8. https://doi.org/10.1080/026404198366425 
921 Usabiaga, J., Crespo, R., Iza, I., Aramendi, J., Terrados, N., \& Poza, J. J. (1997). Adaptation of 922 the lumbar spine to different positions in bicycle racing. Spine, 22(17), 1965-1969.

923 Voutsinas, S. A., \& MacEwen, G. D. (1986). Sagittal profiles of the spine. Clin Orthop Relat R, 924 (210), 235-42.

925 Wilke, H. J., Neef, P., Caimi, M., Hoogland, T., \& Claes, L. E. (1999). New in vivo

926 measurements of pressures in the intervertebral disc in daily life. Spine, 24(8), 755-62.

927 Wodecki, P., Guigui, P., Hanotel, M. C., Cardinne, L., \& Deburge, A. (2002). Sagittal alignment 928 of the spine: Comparison between soccer players and subjects without sports activities. Rev Chir 929 Orthop, 88(4), 328-36.

930 Wojtys, E. M., Ashton-Miller, J. A., Huston, L. J., \& Moga, P. J. (2000). The association

931 between athletic training time and the sagittal curvature of the immature spine. Am J Sports Med, 932 28(4), 490-8. https://doi.org/10.1177/03635465000280040801 


\section{Figure 1}

Assessment positions for the 'Sagittal Integrative Morphotype' protocol.
(A) SP. (B) SSP. (C) MFT.

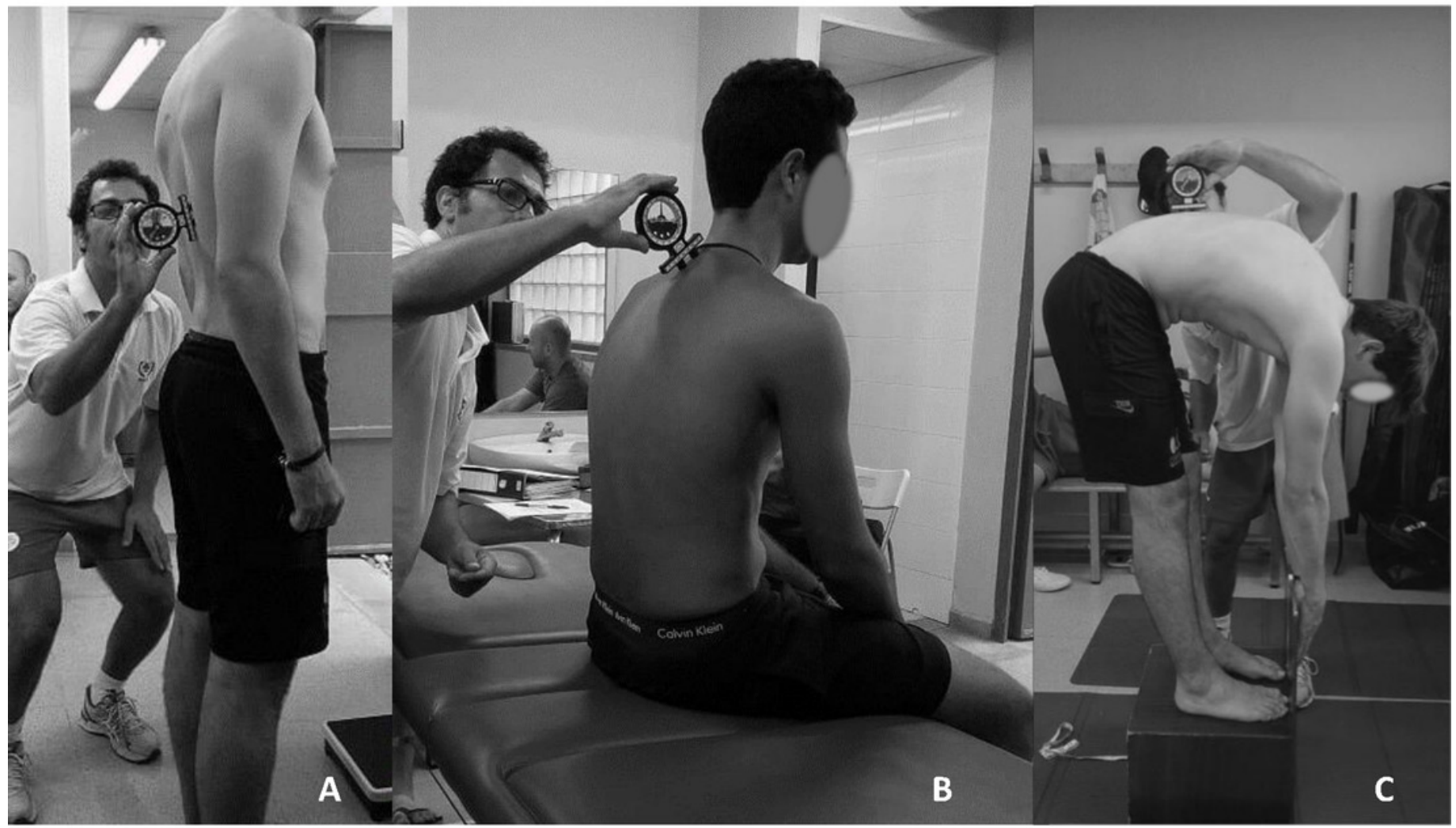




\section{Figure 2}

Hip joint angle test for the measurement of the $\mathrm{L}-\mathrm{H}$ fx in a maximal flexion of the trunk. $A$ : recorded angle; $B$ : supplementary angle.

(A) recorded angle. (B) supplementary angle.

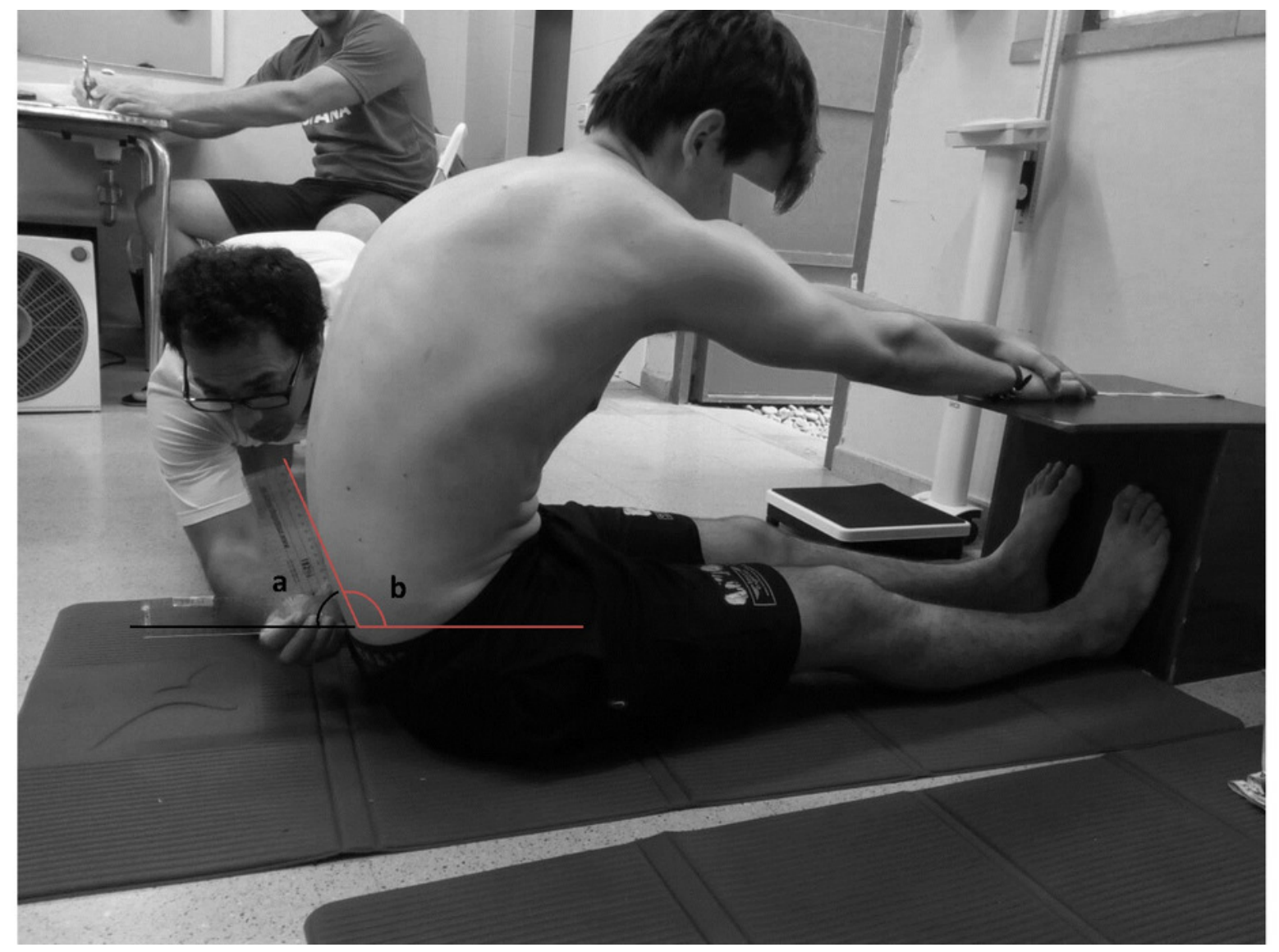


Figure 3

Frequency and percentage of $\mathrm{IH}$ players by category of thoracic curve in each of the three positions

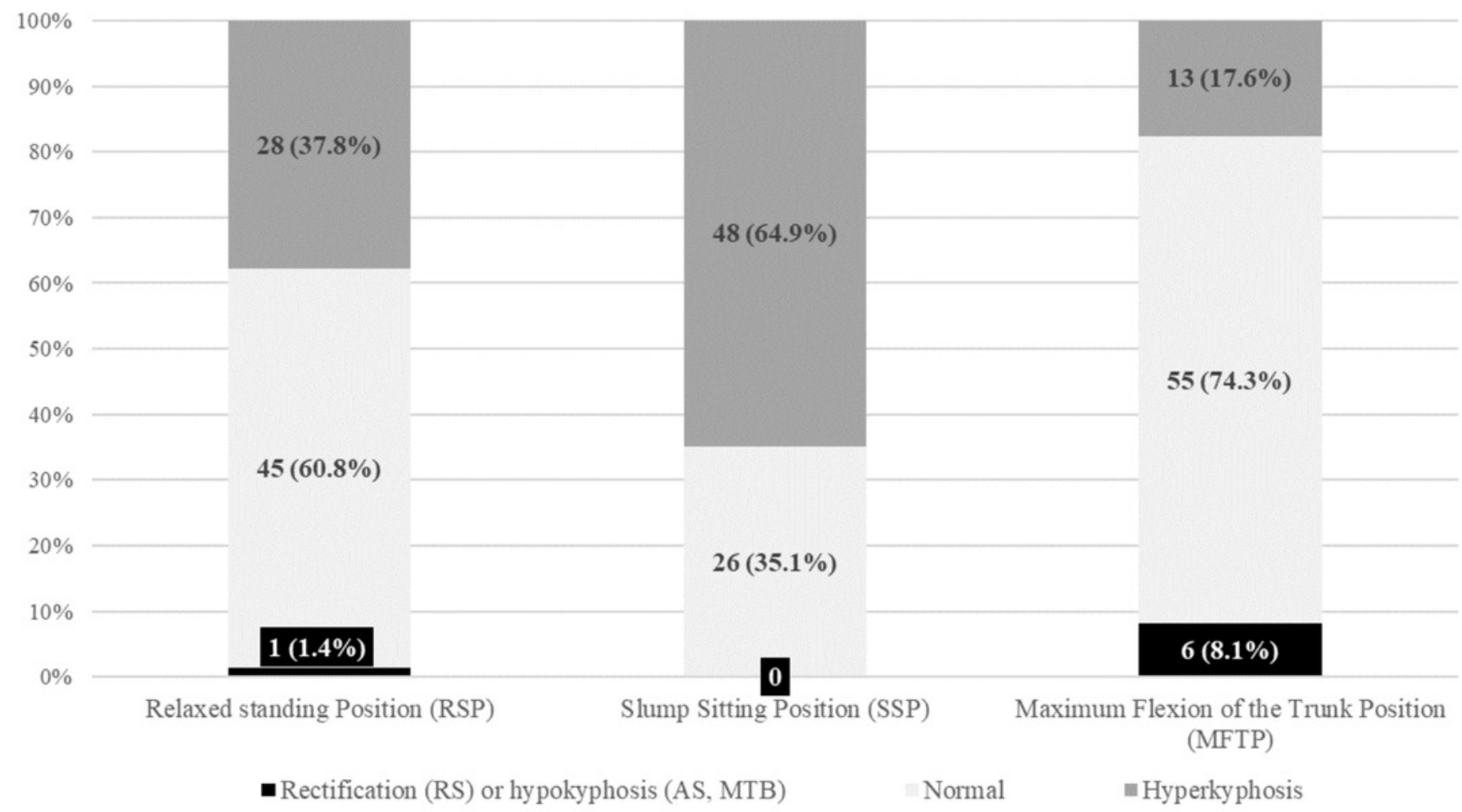


Figure 4

Frequency and percentage of IH players by category of lumbar curvature according to normality references in each position

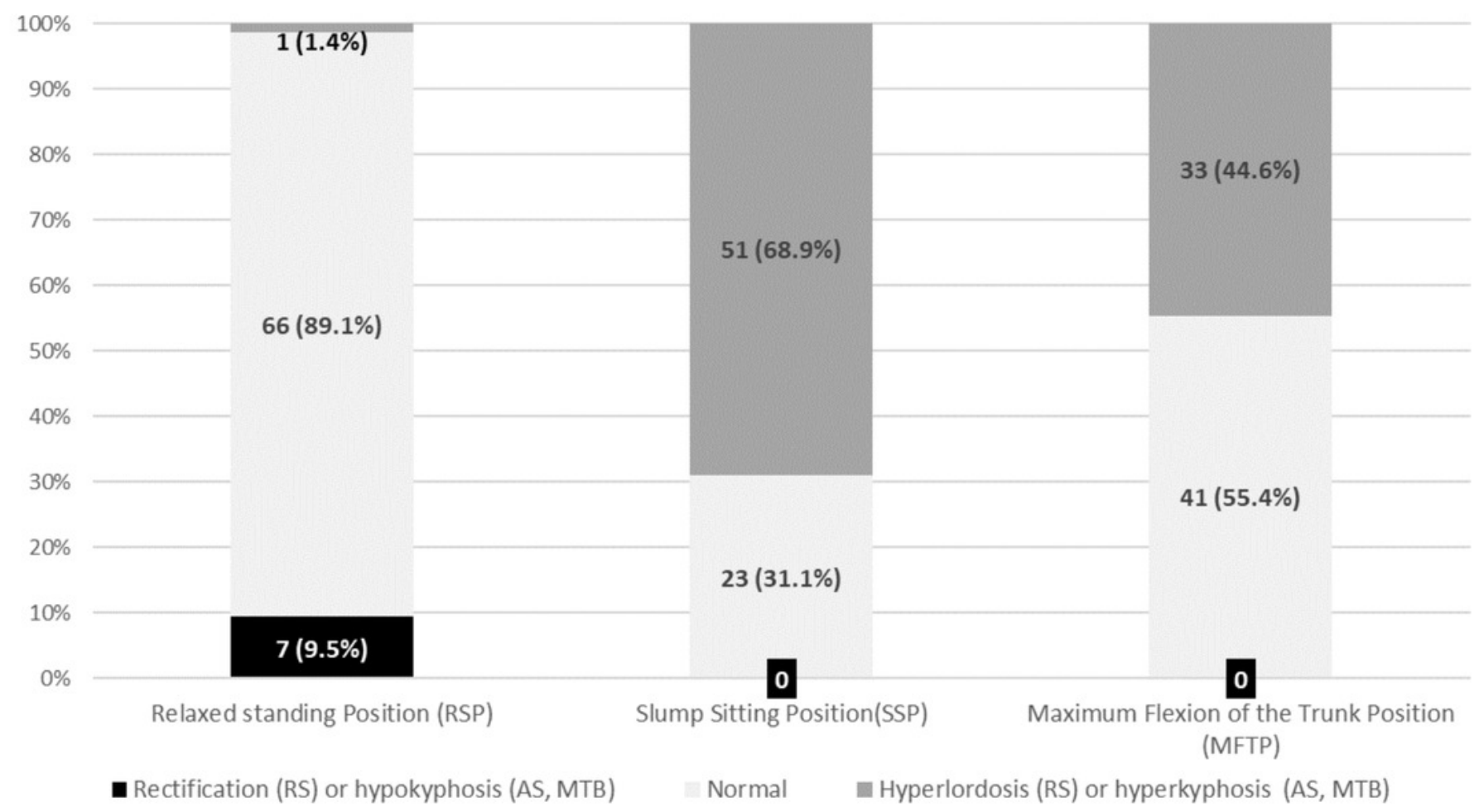




\section{Table $\mathbf{1}$ (on next page)}

Demographic and training data of the U16 IH players $(n=74) *$

*SD: standard deviation; BMI: body mass index. 
Table 1. Demographic and training data of the IH players $(\mathrm{n}=74)^{*}$

\begin{tabular}{cccc}
\hline & Minimum & Maximum & Mean \pm SD \\
\hline Age (years) & 8.0 & 15.0 & $12.1 \pm 1.8$ \\
Body weight $(\mathrm{kg})$ & 27.0 & 86.1 & $51.5 \pm 12.7$ \\
Height $(\mathrm{cm})$ & 1.30 & 1.83 & $1.55 \pm .12$ \\
BMI $\left(\mathrm{kg} / \mathrm{m}^{2}\right)$ & 15.0 & 28.6 & $21.1 \pm 3.4$ \\
Training hours per year & 72.0 & 308.0 & $164.45 \pm 49.95$ \\
Training volume & 96.0 & 2160.0 & $608.67 \pm 469.46$ \\
Stick length (cm) & 108.0 & 155.0 & $134.1 \pm 10.4$ \\
\hline
\end{tabular}

*SD: standard deviation; BMI: body mass index. 


\section{Table 2 (on next page)}

References of normality for thoracic and lumbar curvatures in each position (Ginés-Diaz et al., 2019; Sanz-Mengibar et al., 2018).

*SP=Standing position; SSP=Slump sitting position; MFT=Maximum flexion of the trunk. 
Table 2. References of normality for thoracic and lumbar curvatures in each position (Ginés-Diaz et al., 2019; Sanz-Mengibar et al., 2018).

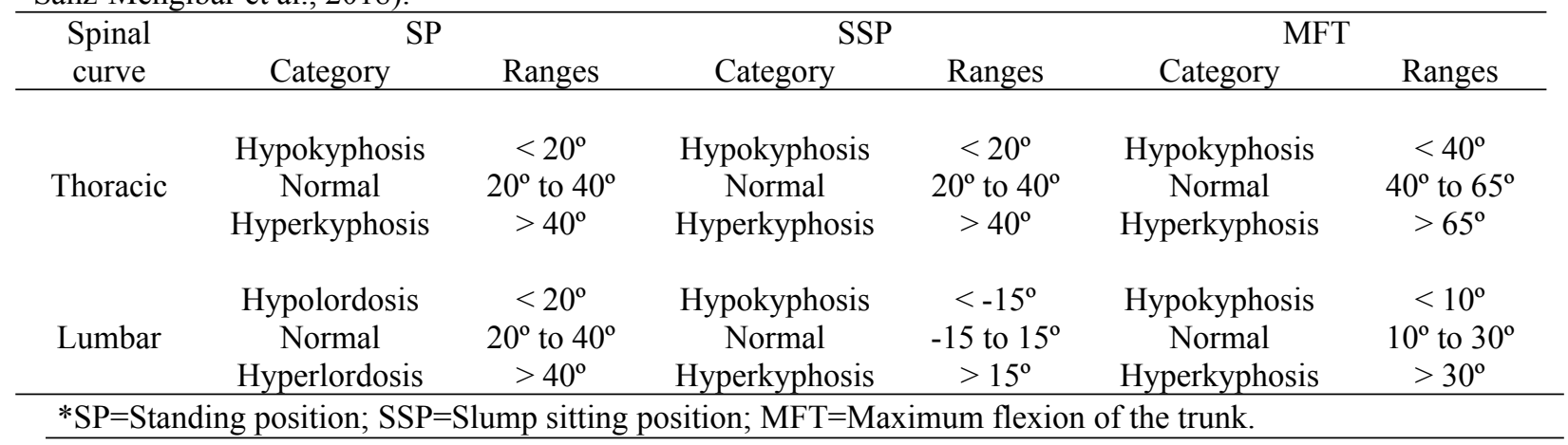




\section{Table 3(on next page)}

Classification for thoracic curve's integrative morphotype diagnosis

*SP=Standing position; SSP=Slump sitting position; MFT=Maximum flexion of the trunk. 
Table 3. Classification for thoracic curve's integrative morphotype diagnosis

\begin{tabular}{|c|c|c|c|c|}
\hline Category & Subcategory & SP & SSP & MFT \\
\hline Normal kyphosis & & $\begin{array}{c}\text { Normal } \\
\left(20^{\circ}-40^{\circ}\right)\end{array}$ & $\begin{array}{c}\text { Normal } \\
\left(20^{\circ}-40^{\circ}\right)\end{array}$ & $\begin{array}{c}\text { Normal } \\
\left(40^{\circ}-65^{\circ}\right)\end{array}$ \\
\hline \multirow{3}{*}{$\begin{array}{l}\text { Functional } \\
\text { Thoracic } \\
\text { Hyperkyphois }\end{array}$} & Static & $\begin{array}{c}\text { Normal } \\
\left(20^{\circ}-40^{\circ}\right) \\
\end{array}$ & $\begin{array}{c}\text { Hyperkyphosis } \\
\left(>40^{\circ}\right)\end{array}$ & $\begin{array}{c}\text { Normal } \\
\left(40^{\circ}-65^{\circ}\right)\end{array}$ \\
\hline & Dynamic & $\begin{array}{c}\text { Normal } \\
\left(20^{\circ}-40^{\circ}\right)\end{array}$ & $\begin{array}{c}\text { Normal } \\
\left(20^{\circ}-40^{\circ}\right)\end{array}$ & $\begin{array}{l}\text { Hyperkyphosis } \\
\left(>65^{\circ}\right)\end{array}$ \\
\hline & Total & $\begin{array}{c}\text { Normal } \\
\left(20^{\circ}-40^{\circ}\right)\end{array}$ & $\begin{array}{c}\text { Hyperkyphosis } \\
\left(>40^{\circ}\right)\end{array}$ & $\begin{array}{c}\text { Hyperkyphosis } \\
\left(>65^{\circ}\right)\end{array}$ \\
\hline \multirow{4}{*}{ Hyperkyphosis } & Total & $\begin{array}{c}\text { Hyperkyphosis } \\
\left(>40^{\circ}\right)\end{array}$ & $\begin{array}{c}\text { Hyperkyphosis } \\
\left(>40^{\circ}\right)\end{array}$ & $\begin{array}{c}\text { Hyperkyphosis } \\
\left(>65^{\circ}\right)\end{array}$ \\
\hline & Standing & $\begin{array}{c}\text { Hyperkyphosis } \\
\left(>40^{\circ}\right)\end{array}$ & $\begin{array}{c}\text { Normal } \\
\left(20^{\circ}-40^{\circ}\right) \\
\end{array}$ & $\begin{array}{c}\text { Normal } \\
\left(40^{\circ}-65^{\circ}\right) \\
\end{array}$ \\
\hline & Static & $\begin{array}{c}\text { Hyperkyphosis } \\
\left(>40^{\circ}\right)\end{array}$ & $\begin{array}{c}\text { Hyperkyphosis } \\
\left(>40^{\circ}\right)\end{array}$ & $\begin{array}{c}\text { Normal } \\
\left(40^{\circ}-65^{\circ}\right)\end{array}$ \\
\hline & Dynamic & $\begin{array}{c}\text { Hyperkyphosis } \\
\left(>40^{\circ}\right)\end{array}$ & $\begin{array}{c}\text { Normal } \\
\left(20^{\circ}-40^{\circ}\right)\end{array}$ & $\begin{array}{c}\text { Hyperkyphosis } \\
\left(>65^{\circ}\right)\end{array}$ \\
\hline \multirow{4}{*}{$\begin{array}{c}\text { Hypokyphosis or } \\
\text { hypokyphotic } \\
\text { attitude }\end{array}$} & Flat back & $\begin{array}{c}\text { Hypokyphosis } \\
\left(<20^{\circ}\right)\end{array}$ & $\begin{array}{c}\text { Hypokyphosis } \\
\left(<20^{\circ}\right)\end{array}$ & $\begin{array}{c}\text { Hypokyphosis } \\
\left(<40^{\circ}\right)\end{array}$ \\
\hline & Standing & $\begin{array}{c}\text { Hypokyphosis } \\
\left(<20^{\circ}\right) \\
\end{array}$ & $\begin{array}{c}\text { Normal } \\
\left(20^{\circ}-40^{\circ}\right) \\
\end{array}$ & $\begin{array}{c}\text { Normal } \\
\left(40^{\circ}-65^{\circ}\right)\end{array}$ \\
\hline & Static & $\begin{array}{c}\text { Hypokyphosis } \\
\left(<20^{\circ}\right)\end{array}$ & $\begin{array}{c}\text { Hypokyphosis } \\
\left(<20^{\circ}\right)\end{array}$ & $\begin{array}{c}\text { Normal } \\
\left(40^{\circ}-65^{\circ}\right) \\
\end{array}$ \\
\hline & Dynamic & $\begin{array}{l}\text { Hypokyphosis } \\
\left(<20^{\circ}\right)\end{array}$ & $\begin{array}{c}\text { Normal } \\
\left(20^{\circ}-40^{\circ}\right)\end{array}$ & $\begin{array}{l}\text { Hypokyphosis } \\
\left(<40^{\circ}\right)\end{array}$ \\
\hline $\begin{array}{c}\text { Hypomobile } \\
\text { kyphosis }\end{array}$ & & $\begin{array}{c}\text { Normal } \\
\left(20^{\circ}-40^{\circ}\right)\end{array}$ & $\begin{array}{l}\text { Normal } \\
\left(20^{\circ}-40^{\circ}\right)\end{array}$ & $\begin{array}{c}\text { Hypokyphosis } \\
\left(<40^{\circ}\right)\end{array}$ \\
\hline
\end{tabular}

* $\mathrm{SP}=$ Standing position; $\mathrm{SSP}=$ Slump sitting position; MFT=Maximum flexion of the trunk. 


\section{Table 4 (on next page)}

Classification for the diagnosis of sagittal integrative lumbar morphotype.

*SP=Standing position; SSP=Slump sitting position; MFT=Maximum flexion of the trunk. 
Table 4. Classification for the diagnosis of sagittal integrative lumbar morphotype.

\begin{tabular}{|c|c|c|c|c|}
\hline Category & Subcategory & $\mathrm{SP}$ & SSP & MFT \\
\hline Normal lumbar curve & & $\begin{array}{c}\text { Normal } \\
\left(20^{\circ}-40^{\circ}\right) \\
\end{array}$ & $\begin{array}{l}\text { Normal } \\
\left(0 \pm 15^{\circ}\right) \\
\end{array}$ & $\begin{array}{c}\text { Normal } \\
\left(10^{\circ}-30^{\circ}\right) \\
\end{array}$ \\
\hline \multirow{2}{*}{$\begin{array}{l}\text { Lumbar spine with reduced } \\
\text { mobility }\end{array}$} & $\begin{array}{c}\text { Functional lumbar } \\
\text { lordosis or hypomobile } \\
\text { lordosis }\end{array}$ & $\begin{array}{l}\text { Normal } \\
\left(20^{\circ}-40^{\circ}\right)\end{array}$ & $\begin{array}{l}\text { Normal } \\
\left(0 \pm 15^{\circ}\right)\end{array}$ & $\begin{array}{c}\text { Hypokyphosis or } \\
\text { lordosis } \\
\left(<10^{\circ}\right) \\
\end{array}$ \\
\hline & Lumbar hypomobility & $\begin{array}{l}\text { Hypolordosis } \\
\left(<20^{\circ}\right)\end{array}$ & $\begin{array}{l}\text { Normal } \\
\left(0 \pm 15^{\circ}\right)\end{array}$ & $\begin{array}{c}\text { Hypokyphosis } \\
\left(<10^{\circ}\right)\end{array}$ \\
\hline Hyperlordotic attitude & & $\begin{array}{l}\text { Hyperlordosis } \\
\left(>40^{\circ}\right)\end{array}$ & $\begin{array}{l}\text { Normal } \\
\left(0 \pm 15^{\circ}\right)\end{array}$ & $\begin{array}{l}\text { Normal } \\
\left(10^{\circ}-30^{\circ}\right) \\
\end{array}$ \\
\hline \multirow{3}{*}{$\begin{array}{l}\text { Functional lumbar } \\
\text { hyperkyphosis }\end{array}$} & Static & $\begin{array}{c}\text { Normal } \\
\left(20^{\circ}-40^{\circ}\right)\end{array}$ & $\begin{array}{l}\text { Hyperkyphosis } \\
\left(>15^{\circ}\right)\end{array}$ & $\begin{array}{l}\text { Normal } \\
\left(10^{\circ}-30^{\circ}\right)\end{array}$ \\
\hline & Dynamic & $\begin{array}{l}\text { Normal } \\
\left(20^{\circ}-40^{\circ}\right)\end{array}$ & $\begin{array}{l}\text { Normal } \\
\left(0 \pm 15^{\circ}\right) \\
\end{array}$ & $\begin{array}{l}\text { Hyperkyphosis } \\
\left(>30^{\circ}\right)\end{array}$ \\
\hline & Total & $\begin{array}{c}\text { Normal } \\
\left(20^{\circ}-40^{\circ}\right) \\
\end{array}$ & $\begin{array}{c}\text { Hyperkyphosis } \\
\left(>15^{\circ}\right)\end{array}$ & $\begin{array}{c}\text { Hyperkyphosis } \\
\left(>30^{\circ}\right)\end{array}$ \\
\hline \multirow{3}{*}{ Lumbar Hypermobility } & Hypermobility 1 & $\begin{array}{l}\text { Hyperlordosis } \\
\left(>40^{\circ}\right)\end{array}$ & $\begin{array}{l}\text { Hyperkyphosis } \\
\left(>15^{\circ}\right)\end{array}$ & $\begin{array}{l}\text { Hyperkyphosis } \\
\left(>30^{\circ}\right)\end{array}$ \\
\hline & Hypermobility 2 & $\begin{array}{l}\text { Hyperlordosis } \\
\left(>40^{\circ}\right)\end{array}$ & $\begin{array}{l}\text { Normal } \\
\left(0 \pm 15^{\circ}\right)\end{array}$ & $\begin{array}{l}\text { Hyperkyphosis } \\
\left(>30^{\circ}\right)\end{array}$ \\
\hline & Hypermobility 3 & $\begin{array}{l}\text { Hyperlordosis } \\
\left(>40^{\circ}\right)\end{array}$ & $\begin{array}{c}\text { Hyperkyphosis } \\
\left(>15^{\circ}\right)\end{array}$ & $\begin{array}{c}\text { Normal } \\
\left(10^{\circ}-30^{\circ}\right)\end{array}$ \\
\hline \multirow{4}{*}{ Hypolordosis } & Hypolordotic attitude & $\begin{array}{c}\text { Hypolordosis } \\
\left(<20^{\circ}\right)\end{array}$ & $\begin{array}{l}\text { Normal } \\
\left(0 \pm 15^{\circ}\right) \\
\end{array}$ & $\begin{array}{c}\text { Normal } \\
\left(10^{\circ}-30^{\circ}\right) \\
\end{array}$ \\
\hline & Lumbar kyphosis 1 & $\begin{array}{c}\text { Hypolordosis } \\
\left(<20^{\circ}\right)\end{array}$ & $\begin{array}{c}\text { Hyperkyphosis } \\
\left(>15^{\circ}\right)\end{array}$ & $\begin{array}{c}\text { Hyperkyphosis } \\
\left(>30^{\circ}\right)\end{array}$ \\
\hline & Lumbar kyphosis 2 & $\begin{array}{c}\text { Hypolordosis } \\
\left(<20^{\circ}\right)\end{array}$ & $\begin{array}{l}\text { Hyperkyphosis } \\
\left(>15^{\circ}\right)\end{array}$ & $\begin{array}{l}\text { Normal } \\
\left(10^{\circ}-30^{\circ}\right) \\
\end{array}$ \\
\hline & Lumbar kyphosis 3 & $\begin{array}{c}\text { Hypolordosis } \\
\left(<20^{\circ}\right)\end{array}$ & $\begin{array}{l}\text { Normal } \\
\left(0 \pm 15^{\circ}\right) \\
\end{array}$ & $\begin{array}{c}\text { Hyperkyphosis } \\
\left(>30^{\circ}\right)\end{array}$ \\
\hline Structured Hyperlordosis & & $\begin{array}{l}\text { Hyperlordosis } \\
\quad\left(>40^{\circ}\right)\end{array}$ & $\begin{array}{c}\text { Hyperlordosis } \\
\left(<-15^{\circ}\right) \text { or } \\
\text { normal } \\
\left(0 \pm 15^{\circ}\right)\end{array}$ & $\begin{array}{l}\text { Lordosis or } \\
\text { Hypokyphosis } \\
\left(<10^{\circ}\right)\end{array}$ \\
\hline Structured lumbar kyphosis & & $\begin{array}{l}\text { Hypolordosis or } \\
\text { kyphosis } \\
\left(<20^{\circ}\right)\end{array}$ & $\begin{array}{l}\text { Hyperkyphosis } \\
\left(>15^{\circ}\right)\end{array}$ & $\begin{array}{l}\text { Hyperkyphosis } \\
\left(>30^{\circ}\right)\end{array}$ \\
\hline
\end{tabular}

*SP=Standing position; $\mathrm{SSP}=$ Slump sitting position; MFT=Maximum flexion of the trunk. 


\section{Table 5 (on next page)}

Mean values of spinal curvatures, minimum and maximum of players within each position and for the pelvic disposition*.

*SP=Standing position; SSP=Slump sitting position; MFT=Maximum flexion of the trunk; $\mathrm{L}-\mathrm{H}$ $f x=$ Lumbo- Horizontal angle in flexion. 
Table 5. Mean values $( \pm \mathrm{SD})$ of spinal curvatures by Spanish Federative Categories, training hours per years and training volume of players within each position and for the pelvic disposition

\begin{tabular}{|c|c|c|c|c|c|c|c|c|c|}
\hline \multirow{2}{*}{\multicolumn{3}{|c|}{ Variables }} & \multicolumn{3}{|c|}{ Thoracic curve (degrees) } & \multicolumn{3}{|c|}{ Lumbar curve (degrees) } & \multirow{2}{*}{$\begin{array}{c}\text { Pelvic L-Hfx } \\
\text { (degrees) }\end{array}$} \\
\hline & & & SP & SSP & MFT & SP & SSP & MFT & \\
\hline \multicolumn{3}{|c|}{ Total $(n=74)$} & $38.5 \pm 7.9$ & $45.2 \pm 11.2$ & $53.7 \pm 10.1$ & $28.7 \pm 7.4$ & $20.3 \pm 10.4$ & $31.5 \pm 8.9$ & $110 \pm 10.8$ \\
\hline & & $\begin{array}{c}\text { U11 } \\
(n=30)\end{array}$ & $38.9 \pm 7$ & $44.5 \pm 8.5$ & $50.3 \pm 9 \dagger$ & $29.6 \pm 7.7$ & $20.1 \pm 10.4$ & $32.3 \pm 8.4$ & $114.1 \pm 9.3 \dagger$ \\
\hline & 范 & $\begin{array}{c}\text { U13 } \\
(n=25)\end{array}$ & $38.9 \pm 7.6$ & $46 \pm 9$ & $54.9 \pm 10.5$ & $28.5 \pm 6.2$ & $21.3 \pm 10.5$ & $32.1 \pm 8.9$ & $107.9 \pm 10.5$ \\
\hline & & $\begin{array}{c}\text { U16 } \\
(n=19)\end{array}$ & $37.2 \pm 9.6$ & $45.2 \pm 16.8$ & $57.5 \pm 9.8 \dagger$ & $27.6 \pm 8.6$ & $19 \pm 9.4$ & $29.3 \pm 9.7$ & $106.2 \pm 11.8 \dagger$ \\
\hline \multirow{2}{*}{ 冓 } & \multirow{2}{*}{ 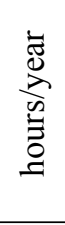 } & $\begin{array}{l}<160 h \\
(n=39)\end{array}$ & $36.7 \pm 8.6^{*}$ & $42 \pm 9.9^{*}$ & $51.6 \pm 9.6$ & $27.6 \pm 8.1$ & $20.1 \pm 10.4$ & $33.3 \pm 8.2$ & $109.9 \pm 11.4$ \\
\hline & & $\begin{array}{l}>160 h \\
(n=35)\end{array}$ & $40.4 \pm 6.6^{*}$ & $48.7 \pm 11.7 *$ & $56 \pm 10.2$ & $29.7 \pm 6.6$ & $20.4 \pm 9.9$ & $29.5 \pm 9.3$ & $110.1 \pm 10.4$ \\
\hline \multirow{2}{*}{ 串 } & \multirow{2}{*}{$\underset{\Xi}{\Xi}$} & $\begin{array}{l}<480 h \\
(n=40)\end{array}$ & $38.7 \pm 7.3$ & $44.4 \pm 8.4$ & $52 \pm 9.4$ & $28.8 \pm 7.4$ & $20.3 \pm 10.9$ & $32.6 \pm 7.5$ & $110.9 \pm 10.7$ \\
\hline & & $\begin{array}{l}>480 h \\
(n=34)\end{array}$ & $38.3 \pm 8.6$ & $46.11 \pm 13.9$ & $55.7 \pm 10.7$ & $28.5 \pm 7.5$ & $20.2 \pm 9.2$ & $30.1 \pm 10.2$ & $109 \pm 11.1$ \\
\hline
\end{tabular}

Note: $\mathrm{SP}=\mathrm{Standing}$ position; $\mathrm{SSP}=\mathrm{Slump}$ sitting position; $\mathrm{MFT}=\mathrm{Maximum}$ flexion of the trunk; L-H $\mathrm{fx}=\mathrm{Lumbo}-$ Horizontal angle in flexion. *Significant differences by training hours per year $(p<0.05)$. $†$ Significant differences by categories $(p<0.05)$. 


\section{Table 6 (on next page)}

Percentage and absolute and relative frequency of players within each category by assessment position for each spinal curve and pelvic disposition according to normality references.

*SP=Standing position; SSP=Slump sitting position; MFT=Maximum flexion of the trunk; $L-H$ $f x=L u m b o-$ Horizontal angle in flexion. 
Table 6. Percentage and absolute and relative frequency of players within each category by assessment position for each spinal curve and pelvic disposition according to normality references.

\begin{tabular}{|c|c|c|c|c|c|}
\hline Variable & Position & Category & Mean \pm SD & $\mathrm{n}$ & $\%$ \\
\hline \multirow{9}{*}{ 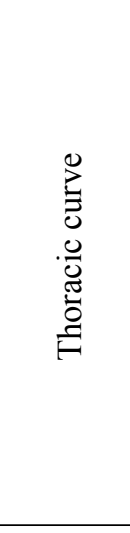 } & \multirow{3}{*}{ SP } & Rectification $\left(<20^{\circ}\right)$ & $16 \pm 0.0^{\circ}$ & 1 & 1.4 \\
\hline & & Normal (20 to $\left.40^{\circ}\right)$ & $34.4 \pm 5.5^{\circ}$ & 45 & 60.8 \\
\hline & & Hyperkyphosis $\left(\geq 41^{\circ}\right)$ & $46 \pm 3.8^{\circ}$ & 28 & 37.8 \\
\hline & \multirow{3}{*}{ SSP } & Hypokyphosis $\left(<20^{\circ}\right)$ & - & 0 & 0 \\
\hline & & Normal $\left(20\right.$ to $\left.40^{\circ}\right)$ & $33.2 \pm 6.4^{\circ}$ & 26 & 35.1 \\
\hline & & Hyperkyphosis $\left(\geq 41^{\circ}\right)$ & $51.4 \pm 7.5^{\circ}$ & 48 & 64.9 \\
\hline & \multirow{3}{*}{ MFT } & Hypokyphosis $\left(<40^{\circ}\right)$ & $36 \pm 2.5^{\circ}$ & 6 & 8.1 \\
\hline & & Normal $\left(40\right.$ to $\left.65^{\circ}\right)$ & $52.3 \pm 7.1^{\circ}$ & 55 & 74.3 \\
\hline & & Hyperkyphosis $\left(\geq 66^{\circ}\right)$ & $68 \pm 1.8^{\circ}$ & 13 & 17.6 \\
\hline \multirow{9}{*}{ 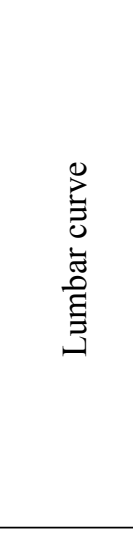 } & \multirow{3}{*}{ SP } & Rectification $\left(<20^{\circ}\right)$ & $14.9 \pm 5.1^{\circ}$ & 7 & 9.5 \\
\hline & & Normal $\left(20\right.$ to $\left.40^{\circ}\right)$ & $29.9 \pm 5.9^{\circ}$ & 66 & 89.2 \\
\hline & & Hyperlordosis $\left(\geq 41^{\circ}\right)$ & $42 \pm 0^{\circ}$ & 1 & 1.4 \\
\hline & \multirow{3}{*}{ SSP } & Hypokyphosis $\left(<-15^{\circ}\right)$ & - & 0 & 0 \\
\hline & & Normal $\left(-15\right.$ to $\left.15^{\circ}\right)$ & $8.2 \pm 4^{\circ}$ & 23 & 31.1 \\
\hline & & Hyperkyphosis $\left(\geq 16^{\circ}\right)$ & $25.7 \pm 6.8^{\circ}$ & 51 & 68.9 \\
\hline & \multirow{3}{*}{ MFT } & Hypokyphosis $\left(<10^{\circ}\right)$ & - & 0 & 0 \\
\hline & & Normal $\left(10\right.$ to $\left.30^{\circ}\right)$ & $24.9 \pm 5.1^{\circ}$ & 41 & 55.4 \\
\hline & & Hyperkyphosis $\left(\geq 31^{\circ}\right)$ & $38.8 \pm 4.9^{\circ}$ & 33 & 44.6 \\
\hline \multirow{3}{*}{ 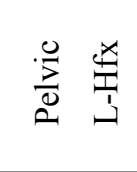 } & \multirow{3}{*}{ MFT } & Normal $\left(<100^{\circ}\right)$ & $94.1 \pm 3.8$ & 12 & 16.2 \\
\hline & & Mild posterior pelvic tilt ( 100 to $\left.110^{\circ}\right)$ & $103.8 \pm 2.9$ & 31 & 41.9 \\
\hline & & Moderate posterior pelvic tilt $\left(>110^{\circ}\right)$ & $113.5 \pm 3.6$ & 31 & 41.9 \\
\hline
\end{tabular}

*SP=Standing position; $\mathrm{SSP}=$ Slump sitting position; MFT=Maximum flexion of the trunk; L-H fx=LumboHorizontal angle in flexion. 


\section{Table 7 (on next page)}

Absolute and relative frequency of $I H$ players within each category of thoracic integrative morphotype . $^{\text {. }}$

${ }^{a} n$ : number of cases; \%: number of cases with respect to the total IH players; ${ }^{*}$ Classification of thoracic integrative morphotype according to thoracic values in SP, SSP and in MFT (Santonja, 1996). 
Table 7. Absolute and relative frequency of IH players within each category of thoracic integrative morphotype . $^{\text {. }}$

\begin{tabular}{|c|c|c|c|c|c|c|}
\hline \multirow{2}{*}{ Category } & \multirow{2}{*}{ Subcategory } & \multicolumn{3}{|c|}{ Classification for integrative thoracic morphotype* } & \multirow{2}{*}{$\mathrm{n}$} & \multirow{2}{*}{$\%$} \\
\hline & & SP & SSP & MFT & & \\
\hline $\begin{array}{c}\text { Hypokyphosis } \\
\text { or hypokyphotic } \\
\text { attitude } \\
\end{array}$ & Standing & $\begin{array}{l}\text { Hypokyphosis } \\
\left(<20^{\circ}\right)\end{array}$ & $\begin{array}{l}\text { Normal } \\
\left(20-40^{\circ}\right)\end{array}$ & $\begin{array}{l}\text { Normal } \\
\left(40-65^{\circ}\right)\end{array}$ & 1 & 1.4 \\
\hline $\begin{array}{c}\text { Hypomobile } \\
\text { kyphosis }\end{array}$ & & $\begin{array}{l}\text { Normal } \\
\left(20-40^{\circ}\right) \\
\end{array}$ & $\begin{array}{l}\text { Normal } \\
\left(20-40^{\circ}\right) \\
\end{array}$ & $\begin{array}{c}\text { Hypokyphosis } \\
\left(<40^{\circ}\right)\end{array}$ & 1 & 1.4 \\
\hline $\begin{array}{l}\text { Normal } \\
\text { Kyphosis }\end{array}$ & & $\begin{array}{l}\text { Normal } \\
\left(20-40^{\circ}\right) \\
\end{array}$ & $\begin{array}{l}\text { Normal } \\
\left(20-40^{\circ}\right) \\
\end{array}$ & $\begin{array}{l}\text { Normal } \\
\left(40-65^{\circ}\right) \\
\end{array}$ & 13 & 17.6 \\
\hline \multirow{4}{*}{ Hyperkyphosis } & Total & $\begin{array}{l}\text { Hyperkyphosis } \\
\left(>40^{\circ}\right)\end{array}$ & $\begin{array}{l}\text { Hyperkyphosis } \\
\left(>40^{\circ}\right)\end{array}$ & $\begin{array}{l}\text { Hyperkyphosis } \\
\left(>65^{\circ}\right)\end{array}$ & 12 & 16.2 \\
\hline & Standing & $\begin{array}{l}\text { Hyperkyphosis } \\
\left(>40^{\circ}\right)\end{array}$ & $\begin{array}{l}\text { Normal } \\
\left(20-40^{\circ}\right)\end{array}$ & $\begin{array}{l}\text { Normal } \\
\left(40-65^{\circ}\right) \\
\end{array}$ & 4 & 5.4 \\
\hline & Static & $\begin{array}{c}\text { Hyperkyphosis } \\
\left(>40^{\circ}\right) \\
\end{array}$ & $\begin{array}{c}\text { Hyperkyphosis } \\
\left(>40^{\circ}\right)\end{array}$ & $\begin{array}{l}\text { Normal } \\
\left(40-65^{\circ}\right) \\
\end{array}$ & 9 & 12.2 \\
\hline & Dynamic & $\begin{array}{c}\text { Hyperkyphosis } \\
\left(>40^{\circ}\right)\end{array}$ & $\begin{array}{l}\text { Normal } \\
\left(20-40^{\circ}\right) \\
\end{array}$ & $\begin{array}{c}\text { Hyperkyphosis } \\
\left(>65^{\circ}\right)\end{array}$ & 3 & 4.1 \\
\hline \multirow{3}{*}{$\begin{array}{c}\text { Functional } \\
\text { hyperkyphosis }\end{array}$} & Static & $\begin{array}{l}\text { Normal } \\
\left(20-40^{\circ}\right)\end{array}$ & $\begin{array}{c}\text { Hyperkyphosis } \\
\left(>40^{\circ}\right)\end{array}$ & $\begin{array}{l}\text { Normal } \\
\left(40-65^{\circ}\right) \\
\end{array}$ & 13 & 17.6 \\
\hline & Dynamic & $\begin{array}{l}\text { Normal } \\
\left(20-40^{\circ}\right)\end{array}$ & $\begin{array}{l}\text { Normal } \\
\left(20-40^{\circ}\right)\end{array}$ & $\begin{array}{c}\text { Hyperkyphosis } \\
\left(>65^{\circ}\right)\end{array}$ & 4 & 5.4 \\
\hline & Total & $\begin{array}{l}\text { Normal } \\
\left(20-40^{\circ}\right)\end{array}$ & $\begin{array}{c}\text { Hyperkyphosis } \\
\left(>40^{\circ}\right)\end{array}$ & $\begin{array}{c}\text { Hyperkyphosis } \\
\left(>65^{\circ}\right)\end{array}$ & 14 & 18.9 \\
\hline
\end{tabular}

${ }^{a}$ n: number of cases; \%: number of cases with respect to the total IH players; *Classification of thoracic integrative morphotype according to thoracic values in SP, SSP and in MFT (Santonja, 1996). 


\section{Table 8(on next page)}

Absolute and relative frequency of IH players within each category of integrative lumbar morphotype ${ }^{a}$.

${ }^{a} n$ : number of cases; \%: number of cases with respect to the total IH players; *Classification of integrative thoracic morphotype according to thoracic values in a SP, in a SSP and in MFT (Santonja, 1996). 
Table 8. Absolute and relative frequency of IH players within each category of integrative lumbar morphotype ${ }^{\mathrm{a}}$.

\begin{tabular}{|c|c|c|c|c|c|c|}
\hline \multirow{2}{*}{ Category } & \multirow{2}{*}{ Subcategory } & \multicolumn{3}{|c|}{ Classification for integrative lumbar morphotype* } & \multirow{2}{*}{$\mathrm{n}$} & \multirow{2}{*}{$\%$} \\
\hline & & SP & SSP & MFT & & \\
\hline Hypolordosis & $\begin{array}{l}\text { Lumbar } \\
\text { hypomobility }\end{array}$ & $\begin{array}{c}\text { Hypolordotic } \\
\text { attitude } \\
\left(<20^{\circ}\right) \\
\end{array}$ & $\begin{array}{l}\text { Normal } \\
\left(0 \pm 15^{\circ}\right)\end{array}$ & $\begin{array}{l}\text { Normal } \\
\left(10-30^{\circ}\right)\end{array}$ & 2 & 2.7 \\
\hline $\begin{array}{c}\text { Normal } \\
\text { lumbar curve } \\
\end{array}$ & & $\begin{array}{l}\text { Normal } \\
\left(20-40^{\circ}\right) \\
\end{array}$ & $\begin{array}{l}\text { Normal } \\
\left(0 \pm 15^{\circ}\right) \\
\end{array}$ & $\begin{array}{l}\text { Normal } \\
\left(10-30^{\circ}\right) \\
\end{array}$ & 17 & 23 \\
\hline \multirow{3}{*}{$\begin{array}{c}\text { Functional } \\
\text { Lumbar } \\
\text { hyperkyphosis }\end{array}$} & Static & $\begin{array}{l}\text { Normal } \\
\left(20-40^{\circ}\right) \\
\end{array}$ & $\begin{array}{c}\text { Hyperkyphosis } \\
\left(>15^{\circ}\right)\end{array}$ & $\begin{array}{l}\text { Normal } \\
\left(10-30^{\circ}\right) \\
\end{array}$ & 15 & 20.3 \\
\hline & Dynamic & $\begin{array}{l}\text { Normal } \\
\left(20-40^{\circ}\right) \\
\end{array}$ & $\begin{array}{l}\text { Normal } \\
\left(0 \pm 15^{\circ}\right) \\
\end{array}$ & $\begin{array}{c}\text { Hyperkyphosis } \\
\left(>30^{\circ}\right)\end{array}$ & 4 & 5.4 \\
\hline & Total & $\begin{array}{l}\text { Normal } \\
\left(20-40^{\circ}\right) \\
\end{array}$ & $\begin{array}{l}\text { Hyperkyphosis } \\
\left(>15^{\circ}\right)\end{array}$ & $\begin{array}{c}\text { Hyperkyphosis } \\
\left(10-30^{\circ}\right)\end{array}$ & 30 & 40.5 \\
\hline $\begin{array}{l}\text { Lumbar } \\
\text { hypermobility }\end{array}$ & & $\begin{array}{l}\text { Hyperlordosis } \\
\qquad\left(>40^{\circ}\right)\end{array}$ & $\begin{array}{c}\text { Normal } \\
\left(0 \pm 15^{\circ}\right) \text { or } \\
\text { Hyperkyphosis } \\
\left(>15^{\circ}\right)\end{array}$ & $\begin{array}{l}\text { Normal (10- } \\
\text { 30 }) \text { or } \\
\text { Hyperkyphosis } \\
\quad\left(>30^{\circ}\right)\end{array}$ & 1 & 1.4 \\
\hline $\begin{array}{c}\text { Structured } \\
\text { lumbar } \\
\text { kyphosis }\end{array}$ & & $\begin{array}{c}\text { Hypolordosis } \\
\text { o kyphosis } \\
\left(<20^{\circ}\right)\end{array}$ & $\begin{array}{l}\text { Hyperkyphosis } \\
\qquad\left(>15^{\circ}\right)\end{array}$ & $\begin{array}{l}\text { Hyperkyphosis } \\
\left(>30^{\circ}\right)\end{array}$ & 5 & 6.8 \\
\hline
\end{tabular}

${ }^{a} \mathrm{n}$ : number of cases; \%: number of cases with respect to the total $\mathrm{IH}$ players; *Classification of integrative thoracic morphotype according to thoracic values in a SP, in a SSP and in MFT (Santonja, 1996). 
Table 9 (on next page)

Angular values for thoracic curvature in a relaxed standing position, in a slump sitting position and in maximal trunk flexion in different previous studies. 
Table 9. Angular values for thoracic curvature in a relaxed SP, in a SSP and in MFT in different previous studies by sport.

\begin{tabular}{|c|c|c|c|c|c|c|c|c|c|c|}
\hline & $\begin{array}{l}\text { Present } \\
\text { study } \\
(2019) \\
\end{array}$ & $\begin{array}{l}\text { (Wojtys et } \\
\text { al., 2000) }\end{array}$ & $\begin{array}{l}\text { (Rajabi et } \\
\text { al., 2007) }\end{array}$ & $\begin{array}{l}\text { (Rajabi et } \\
\text { al., 2012) }\end{array}$ & $\begin{array}{l}\text { (Alricsson et } \\
\text { al., 2016) }\end{array}$ & $\begin{array}{l}\text { (Pastor et } \\
\text { al., 2002) }\end{array}$ & $\begin{array}{c}\text { (López- } \\
\text { Miñarro et } \\
\text { al., 2009) }\end{array}$ & $\begin{array}{c}\text { (López- } \\
\text { Miñarro et } \\
\text { al., 2008) }\end{array}$ & $\begin{array}{l}\text { (Sainz de } \\
\text { Baranda et } \\
\text { al., 2009) }\end{array}$ & $\begin{array}{l}\text { (Sanz- } \\
\text { Mengibar et } \\
\text { al., 2018) }\end{array}$ \\
\hline Aged (years) & $8-15$ & $8-18$ & $15-34$ & 18-19 & $16-19$ & $9-15$ & $13-14$ & 13.3 & 14.9 & 15.02 \\
\hline Sports & $\begin{array}{l}\text { Inline } \\
\text { hockey }\end{array}$ & Ice-hockey & Field hockey & Field hockey & $\begin{array}{c}\text { Cross- } \\
\text { Country }\end{array}$ & Swimming & Running & Paddlers & $\begin{array}{l}\text { Trampoline } \\
\text { gymnasts }\end{array}$ & $\begin{array}{c}\text { Artistic } \\
\text { gymnasts }\end{array}$ \\
\hline SP & $38.5^{\circ}$ & $38.1^{\circ}$ & $34.1^{\circ}$ & $\begin{array}{c}\text { Athletes: } \\
41.71^{\circ} \\
\text { Non-athletes: } \\
36.72^{\circ} \\
\end{array}$ & $41.2^{\circ}$ & $\begin{array}{l}\delta^{7}: 40.4^{\circ} \\
+: 39.5^{\circ}\end{array}$ & $45.6^{\circ}$ & $\begin{array}{c}\text { Kayak: } \\
42.2^{\circ} \text { Canoe: } \\
37.4^{\circ}\end{array}$ & $\begin{array}{l}0^{\top}: 46.9^{\circ} \\
+9: 43^{\circ}\end{array}$ & $\begin{array}{l}\delta^{\top}: 39.6^{\circ} \\
\text { +: } 31.8^{\circ}\end{array}$ \\
\hline SSP & $45^{\circ}$ & - & - & 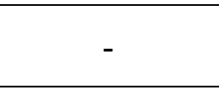 & - & - & - & $\begin{array}{l}\text { Kayak/canoe } \\
\quad: \sim 50^{\circ}\end{array}$ & $\begin{array}{l}0: 51.3^{\circ} \\
0: 49.2^{\circ}\end{array}$ & $\begin{array}{l}\text { o: }: 39.6^{\circ} \\
0: 31.8^{\circ}\end{array}$ \\
\hline \multirow[t]{2}{*}{ MFT } & $53.7^{\circ}$ & & - & - & - & $\begin{array}{l}0^{\lambda}: 78.45^{\circ} \\
0: 73.4^{\circ} \\
\end{array}$ & $63.5^{\circ}$ & $\begin{array}{l}\text { Kayak/canoe } \\
\quad: \sim 65^{\circ}\end{array}$ & $\begin{array}{l}1: 55.7^{\circ} \\
+: 47.4^{\circ}\end{array}$ & $\begin{array}{l}1: 55.5^{\circ} \\
0: 49.3^{\circ} \\
\end{array}$ \\
\hline & $\begin{array}{l}\text { (Sainz de } \\
\text { Baranda et } \\
\text { al., 2010) }\end{array}$ & $\begin{array}{c}\text { (Ferreira \& } \\
\text { Amado, } \\
\text { 2014) }\end{array}$ & $\begin{array}{c}\text { (Grabara, } \\
\text { 2016) }\end{array}$ & $\begin{array}{l}\text { (Grabara, } \\
\text { 2012) }\end{array}$ & $\begin{array}{c}\text { (Grabara, } \\
\text { 2015) }\end{array}$ & $\begin{array}{c}\text { (Grabara \& } \\
\text { Hadzik, } \\
\text { 2009) }\end{array}$ & $\begin{array}{l}\text { (Muyor et } \\
\text { al., 2013) }\end{array}$ & $\begin{array}{l}\text { (Grabara, } \\
\text { 2014) }\end{array}$ & $\begin{array}{l}\text { (Grabara, } \\
\text { 2014b) }\end{array}$ & \\
\hline Aged (years) & 15 & $12-16$ & 13 & $13-15$ & $14-16$ & 13-16 & $13-18$ & $12-15$ & 14-17 & \\
\hline Sports & $\begin{array}{l}\text { Trampoline } \\
\text { gymnasts }\end{array}$ & Basketball & Basketball & Basketball & Volleyball & Volleyball & $\begin{array}{l}\text { Tennis } \\
\text { players }\end{array}$ & Handball & $\begin{array}{c}\text { Volleyball } \\
\text { Basketball } \\
\text { Handball }\end{array}$ & \\
\hline SP & $\begin{array}{c}\text { Training's } \\
\text { hours/ys } \\
\leq 2000 \mathrm{~h}: \\
43.9^{\circ} \\
>2000 \mathrm{~h}: \\
43.9^{\circ} \\
\end{array}$ & $30.4^{\circ}$ & $\begin{array}{l}\text { 1-yes: } 38.5^{\circ} \\
2 \text {-yes: } 35.8^{\circ} \\
\text { 3-yes: } 34.4^{\circ}\end{array}$ & $\begin{array}{c}13-14 \text { yr: } \\
28.8^{\circ} \\
15 \text { yr: } 27.2^{\circ}\end{array}$ & $\begin{array}{l}14 \mathrm{yr}: 30.1^{\circ} \\
15 \mathrm{yr}: 31.1^{\circ} \\
16 \mathrm{yr}: 30.2^{\circ}\end{array}$ & $\begin{array}{c}13-14 \mathrm{yr}: \\
27.2^{\circ} \\
15-16 \mathrm{yr}: \\
29.6^{\circ}\end{array}$ & $\begin{array}{l}\text { o: } 43.8^{\circ} \\
\text { क: } 36.1^{\circ}\end{array}$ & $\begin{array}{l}12 \mathrm{yr}: 27.5^{\circ} \\
13 \mathrm{yr}: 27.2^{\circ} \\
14 \mathrm{yr}: 28.4^{\circ} \\
15 \mathrm{yr}: 28.8^{\circ}\end{array}$ & 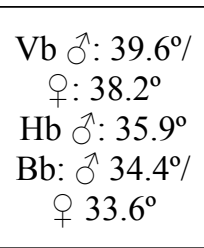 & \\
\hline SSP & $\begin{array}{c}2000 \mathrm{~h}: \\
52.4^{\circ} \\
>2000 \mathrm{~h}: \\
48.9^{\circ}\end{array}$ & - & - & & - & - & - & - & - & \\
\hline MFTT & $\begin{array}{c}\leq 2000 \mathrm{~h}: \\
50.6^{\circ} \\
>2000 \mathrm{~h}: \\
51.2^{\circ}\end{array}$ & - & - & & - & - & - & - & - & \\
\hline
\end{tabular}


Table $\mathbf{1 0}$ (on next page)

Angular values for lumbar curvature in a relaxed SP, in a SSP and in MFT in by sport. 
Table 10. Angular values for lumbar curvature in a relaxed SP, in a SSP and in MFT in different previous studies by sport.

\begin{tabular}{|c|c|c|c|c|c|c|c|c|c|}
\hline 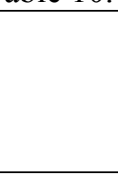 & $\begin{array}{c}\text { Present } \\
\text { study (2019) }\end{array}$ & $\begin{array}{c}\text { (Wojtys et } \\
\text { al., 2000) }\end{array}$ & $\begin{array}{l}\text { (Kujala et } \\
\text { al., 1997) }\end{array}$ & $\begin{array}{c}\text { (Ogurkowsk } \\
\text { a \& } \\
\text { Kawałek, } \\
\text { 2017) } \\
\end{array}$ & $\begin{array}{l}\text { (Alricsson et } \\
\text { al., 2016) }\end{array}$ & $\begin{array}{c}\text { (Grabara, } \\
\text { 2012) }\end{array}$ & $\begin{array}{c}\text { (Ferreira \& } \\
\text { Amado, } \\
\text { 2014) }\end{array}$ & $\begin{array}{c}\text { (Grabara, } \\
2016 b)\end{array}$ & $\begin{array}{c}\text { (Grabara, } \\
\text { 2014a) }\end{array}$ \\
\hline $\begin{array}{c}\begin{array}{c}\text { Aged } \\
\text { (years) }\end{array} \\
\end{array}$ & $8-15$ & $8-18$ & 11.9 & $24-35$ & $16-19$ & $13-15$ & $12-16$ & 13 & $12-15$ \\
\hline Sports & Inline hockey & Ice hockey & Ice hockey & Field hockey & $\begin{array}{c}\text { Cross-country } \\
\text { skiers }\end{array}$ & Basketball & Basketball & Basketball & Handball \\
\hline SP & $28.7^{\circ}$ & $44.5^{\circ}$ & $35^{\circ}$ & 43.2 & $33.4^{\circ}$ & $\begin{array}{c}13-14 \mathrm{yr}: \\
27.6^{\circ} \\
15 \mathrm{yr}: 27.8^{\circ}\end{array}$ & $32.8^{\circ}$ & $\begin{array}{l}\text { 1-yes: } 21.5^{\circ} \\
\text { 2-yes: } 29^{\circ} \\
\text { 3-yes: } 24.6^{\circ}\end{array}$ & $\begin{array}{l}12 \text { yr: } 30.7^{\circ} \\
13 \text { yr: } 28.6^{\circ} \\
14 \text { yr: } 28.1^{\circ} \\
15 \text { yr: } 25.9^{\circ}\end{array}$ \\
\hline SSP & $20.3^{\circ}$ & - & - & - & - & - & - & - & - \\
\hline \multirow[t]{2}{*}{ MFT } & $31.5^{\circ}$ & - & - & - & - & - & - & - & - \\
\hline & $\begin{array}{l}\text { (Grabara, } \\
\text { 2015) }\end{array}$ & $\begin{array}{c}\text { (Grabara \& } \\
\text { Hadzik, } \\
\text { 2009) }\end{array}$ & $\begin{array}{l}\text { (Pastor et } \\
\text { al., 2002) }\end{array}$ & $\begin{array}{c}\text { (López- } \\
\text { Miñarro et } \\
\text { al., 2009) }\end{array}$ & $\begin{array}{c}\text { (Sainz de } \\
\text { Baranda et al., } \\
\text { 2009) }\end{array}$ & $\begin{array}{c}\text { (Sainz de } \\
\text { Baranda et } \\
\text { al., 2010) }\end{array}$ & $\begin{array}{c}\text { (Sanz- } \\
\text { Mengibar et } \\
\text { al., 2018) } \\
\end{array}$ & $\begin{array}{c}\text { (López- } \\
\text { Miñarro et } \\
\text { al., 2008) }\end{array}$ & $\begin{array}{c}\text { (Gómez- } \\
\text { Lozano, } \\
\text { 2007) }\end{array}$ \\
\hline $\begin{array}{c}\begin{array}{c}\text { Aged } \\
\text { (years) }\end{array} \\
\end{array}$ & $14-16$ & $13-16$ & $9-15$ & $13-14$ & 14.9 & 15 & 15.02 & 13.3 & \\
\hline Sports & Volleyball & Volleyball & Swimming & Running & $\begin{array}{c}\text { Trampoline } \\
\text { gymnasts }\end{array}$ & $\begin{array}{c}\text { Trampoline } \\
\text { gymnasts }\end{array}$ & $\begin{array}{c}\text { Artistic } \\
\text { gymnasts }\end{array}$ & $\begin{array}{l}\text { Kayak } \\
\text { Canoe }\end{array}$ & Dancers \\
\hline SP & $\begin{array}{l}14 \text { yr: } 30.1^{\circ} \\
15 \text { yr: } 31.1^{\circ} \\
16 \text { yr: } 30.2^{\circ}\end{array}$ & $\begin{array}{c}13-14 \text { yr: } 28^{\circ} \\
15-16 \mathrm{yr}: \\
25.5^{\circ}\end{array}$ & $\begin{array}{l}\text { ㅈ: } 31.21^{\circ} \\
\text { ㅇ: } 36.33^{\circ}\end{array}$ & $31.2^{\circ}$ & $\begin{array}{l}\text { त. } 32^{\circ} \\
\text { ᄋ: } 40.3^{\circ}\end{array}$ & $\begin{array}{c}\text { Training's } \\
\text { hours/ys } \\
\leq 2000 \mathrm{~h}: \\
31.7^{\circ} \\
>2000 \mathrm{~h}: \\
36.6^{\circ}\end{array}$ & $\begin{array}{l}\text { T: } 39.6^{\circ} \\
+: 30.5^{\circ}\end{array}$ & $\begin{array}{c}\text { Kayak: } 27.9^{\circ} \\
\text { Canoe: } 25.7^{\circ}\end{array}$ & $\begin{array}{l}\text { }: 35.18^{\circ} \\
\text { o: } 33.84^{\circ}\end{array}$ \\
\hline SSP & - & - & & - & $\begin{array}{l}\text { † }: 21^{\mathrm{o}} \\
\text { ○: } 14^{\mathrm{o}}\end{array}$ & $\begin{array}{c}\leq 2000 \mathrm{~h}: 21^{\circ} \\
>2000 \mathrm{~h}: \\
16.4^{\circ}\end{array}$ & $\begin{array}{l}\text { त: } 26.1^{\mathrm{o}} \\
\text { ○: } 27.7^{\mathrm{o}}\end{array}$ & $\begin{array}{c}\text { Kayak/canoe: } \\
\sim 18^{\circ}\end{array}$ & $\begin{array}{l}\text { ㅇ: } 8.33^{\circ} \\
\text { ㅇ: } 8.36^{\circ}\end{array}$ \\
\hline MFT & - & - & $\begin{array}{c}\delta^{\top}: 24,62^{\circ} \\
\text { 足: } 21^{\circ}\end{array}$ & $27.4^{\mathrm{o}}$ & $\begin{array}{l}\text { }: 31.9^{\circ} \\
\text { : } 26.7^{\circ}\end{array}$ & $\begin{array}{c}\leq 2000 \mathrm{~h}: \\
32.3^{\circ} \\
>2000 \mathrm{~h}: \\
27.5^{\circ}\end{array}$ & 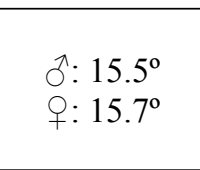 & $\begin{array}{c}\text { Kayak/canoe: } \\
\sim 30^{\circ}\end{array}$ & $\begin{array}{l}\text { o: } 19.82^{\circ} \\
\text { o: } 19.48^{\circ}\end{array}$ \\
\hline
\end{tabular}

